\title{
Spatial variations and abundances of trace metals as linked to landuse pattern: a case study from Gurugram, Haryana, India
}

\author{
Arohi Dixit ${ }^{1} \cdot$ N. Siva Siddaiah ${ }^{1} \cdot$ Prerna Joshi $^{1}$
}

Received: 27 January 2020 / Accepted: 16 June 2020 / Published online: 20 July 2020

(c) Springer Nature Switzerland AG 2020

\begin{abstract}
Surface soil samples $(n=36)$ from different land use areas (rural, industrial, commercial and residential) of Gurugram were studied for physicochemical properties and trace metal $(\mathrm{Cu}, \mathrm{Cr}, \mathrm{Co}, \mathrm{Ni}, \mathrm{Pb}$, and $\mathrm{Zn}$ ) abundances to identify their sources and spatial distribution over the region. Based on the results obtained, the soils of Gurugram, in general, are sandy (75-85 wt\%), alkaline, and unpolluted with moderate pollution at certain sites. The average pH lies near 7.5 in all the land uses. Electrical conductivity in residential $(329 \mu \mathrm{S} / \mathrm{cm})$ soils is almost thrice the value in rural $(87 \mu \mathrm{S} / \mathrm{cm})$ soils. The primary metal of concern is $\mathrm{Zn}$, which is above the permissible limits, followed by $\mathrm{Cu}$ and $\mathrm{Pb}$. Common aluminosilicate minerals observed in the soils are quartz, K-feldspar, muscovite and sodic plagioclases. Based on the calculated average geo-accumulation index (Igeo) values of samples, soils of Gurugram, in general, are uncontaminated and have values $<1$. However, a few samples are moderately contaminated. Soils show moderate contamination based on the average contamination factor values. The pollution load index, which gives cumulative pollution of all the metals for a site, suggests perfection, which means no contamination. Enrichment factor indicates minor enrichment for $\mathrm{Cr}, \mathrm{Cu}$, $\mathrm{Pb}$, and $\mathrm{Zn}$, whereas no enrichment for $\mathrm{Co}$ and $\mathrm{Ni}$ in all the studied sites. In health risk assessment, hazard quotient and hazard index values are $<1$ and show no adverse health effects concerning non-cancer risk. Correlation and principal component analysis suggest $\mathrm{Co}, \mathrm{Cr}$, and $\mathrm{Ni}$ being geologically controlled while control on $\mathrm{Cu}, \mathrm{Pb}$, and $\mathrm{Zn}$ is mixed type i.e., both geological and anthropological. The geochemical maps show a similar spatial distribution for $\mathrm{Cu}, \mathrm{Pb}$, and $\mathrm{Zn}$, which is consistent with the correlation. These metals are dominated in some commercial and residential sites. In general, soils are found to be uncontaminated based on average concentration; however, certain hotspots are observed for $\mathrm{Cu}$, $\mathrm{Pb}$, and $\mathrm{Zn}$, which show moderate pollution and warrants early management.
\end{abstract}

Keywords Urbanisation · Urban soil contamination · Trace metals · Soil pollution indices · Spatial distribution · India

\section{Introduction}

Increasing population density and the development of urban infrastructure led to changing land-use patterns, increased anthropogenic disturbances, and the associated detrimental effects $[24,48]$. With the onset of urbanization and development, the land use of peri-urban areas rapidly changes into residential, industrial, commercial, and other urban land uses $[16,18]$. These disturbances have a tremendous impact on all the compartments (soil-water-air and biota) of any ecosystem, especially soils that serve as the most important source and sink of toxic agents [5].

Urban soils due to their proximity to the human population are most susceptible to contamination [21]. They get contaminated by various anthropogenic activities and reach the human system through different carrier agents

Electronic supplementary material The online version of this article (https://doi.org/10.1007/s42452-020-3087-3) contains supplementary material, which is available to authorized users.

N. Siva Siddaiah, nssiddaiah@mail.jnu.ac.in | 'School of Environmental Sciences, Jawaharlal Nehru University, New Delhi 110067, India. 
(wind, food, and water) via direct ingestion, inhalation, dermal contact, or drinking, leading to serious health problems [44]. Trace metal contamination in soil emerges as the most serious kind of contamination nowadays due to its chronic effects, which surface out on a longer time scale [75].

Trace metals such as $\mathrm{As}, \mathrm{Cd}, \mathrm{Cu}, \mathrm{Hg}, \mathrm{Mn}, \mathrm{Ni}, \mathrm{Pb}$, and $\mathrm{Zn}$ are accumulative, non-degradable, potentially toxic, and ubiquitous $[36,39]$ Due to differences in developmental and other activities in different land-use areas (rural, industrial, residential, or commercial), variations are found in sources and concentrations of these pollutants [16]. Rural soil is most likely to get its contamination from atmospheric fall or agriculture sources, while industrial soils are most susceptible to sources like industrial discharges and industrial waste dumping $[14,76]$. Commercial soils are likely to receive contamination from a mixed type of sources market waste, construction waste, waste from small industries, or shops. In contrast, residential soils receive inputs mostly from household waste and constructions [43]. Parental rock composition and weathering, atmospheric fallout, and vehicular emissions are common sources among different land uses. In a previously agriculture dominated city, agriculture is likely to serve as a common source of pollutants.

Gurugram, one of the highly developed cities of India, is among Delhi's four major satellite cities and thus a part of the National Capital Region (NCR). With the rapid expansion of the Gurugram city, land use pattern has changed dramatically in a short span of time from historically agricultural land to industrial, commercial, residential and different other land uses [35, 42]. Apart from the corporate sector, the largest among all the city hosts industries like automobiles manufacturing, telecommunication equipment, software development, rubber products, electrical goods, sports goods, garments, light engineering goods, pharmaceuticals, food items, air conditioners, footwears, pesticides, insecticides, etc. Hence, environmental quality in the city has severely deteriorated. Although a few studies have been carried out on agriculture $[26,37]$ and groundwater $[31,58]$ aspects, yet very little information is available regarding occurrence and distribution of trace metals in city soils.

We present here, results of detailed and systematic studies, carried out on various aspects of soils of Gurugram, with the objective to investigate the potentially toxic trace metal abundances in the soils, to identify their possible sources (geogenic versus anthropogenic), their concentration variations in the soil as a function of the land-use pattern (rural, industrial, commercial and residential), their spatial distribution in the city to trace the hot spots of pollution and their potential impact on human health and ecosystem. The results of this study will help to fill the knowledge gap, important for providing a baseline for proper environmental planning and future monitoring in the city.

\section{Methods and materials}

\subsection{Study area}

The study area lies in Gurugram (earlier "Gurgaon") district of Haryana, which is also a satellite township of the national capital of India, New Delhi. The district is situated between latitudes $27^{\circ} 39^{\prime} 58^{\prime \prime} \mathrm{N}$ to $28^{\circ} 32^{\prime} 30^{\prime \prime} \mathrm{N}$ and longitudes $76^{\circ} 39^{\prime} 10^{\prime \prime} \mathrm{E}$ to $77^{\circ} 20^{\prime} 27^{\prime \prime} \mathrm{E}$ and falls in the southernmost region of the state. The climate of the district is characterized as tropical steppe, semi-arid and hot. It receives a normal annual rainfall of about $596 \mathrm{~mm}$ spread over 28 days [11, 13, 38]. The annual temperature range is $5^{\circ} \mathrm{C}$ and $40^{\circ} \mathrm{C}$. During most of the months, winds are westerly or north-westerly. A combination of both hills and depressions can be seen in the district, which creates irregular and diverse topography. Ferozpur-Jhirka Delhi ridge forms the western boundary, and Delhi ridge forms the eastern boundary of the district. These hills are the northern continuation of the Aravallis. The district is divided into four distinct landscapes: Aravalli Hills, Foot Hills, Sahibi Flood Plain, and Aeolian Landscape (38).

Geologically, a large part of the district comprises of Pre-Cambrian metasediments of Delhi Super Group and Quaternary alluvium. Delhi super-group is represented by Alwar quartzites, pegmatite intrusive of the Alwar series, slates of phyllites, mica schists, and quartzites of the subrecent alluvium and sand dunes [38]. Low-grade haematite and jasperoid hematite occur in Ferozpur-Jhirka area. Minerals other than haematite include china clay, arsenopyrite, feldspars, garnet, graphite and quartz [42].

Among the different soil types found in Haryana, Ustipsamment type, is frequently distributed by aeolian activity. In the district, they occur on sand dunes of shifting nature. These types of soil are sandy, alkaline and are single grained. The alluvium is of both newer and older nature. A major part of the district comprises of old alluvium, which consists of generally poorly sorted sand, silt and clay. Different types and textures of soils are found in different parts of the districts like tropical and brown soils in northern parts while waterlogged and salt-affected soils in the southern parts $[13,38]$. It is sand to loamy sand in sand dunes and sandy plain areas while it is silty clay loam or sandy loam to clay loam in alluvial plains, calcareous and loamy sand to loam in salt-affected plains and hills and silty loam to loam in lowlands. The overall texture of soils of Gurugram is medium-textured loamy sand [11, 14 , 37]. 
With the rapid expansion of the city, land use has been changed rapidly in a very short span of time. A major portion of agricultural land is converted into residential, industrial, and various other land uses [35]. Gurugram district is divided into four blocks, namely: 1. Farrukhnagar 2. Gurugram 3. Pataudi 4. Sohna. Gurugram block has largely undergone developmental activities (dense industrialization, commercialization and residential developments) and reckless urbanization. Figure 1 shows the study area and distribution of sampling sites.

\subsection{Collection and preparation of sample}

After an extensive field survey in the city, a total of 12 sites (Table 1) were selected for sample collection. Sampling locations were geo-referenced using GPS Garmin (GPS 72H) and classified according to their land use into rural, industrial, commercial, and residential sites. At each site, 2-7 samples were collected from different parks and wastelands according to the availability of sample collection points. A total of 40 surface soil samples from the top $0-15 \mathrm{~cm}$ of the surface were collected from the study area. Samples were brought in the laboratory and processed further for physicochemical, mineralogical and geochemical analysis.

\subsection{Sample analysis}

For the determination of $\mathrm{pH}$ and electrical conductivity (EC), the soil-water suspension method was used. A soil suspension was made using 1:5 soil: water (Milli-Q) ratio for $\mathrm{pH}$ and 1:10 for EC. Suspension made for EC was filtered using Whatman No. 41 filter paper. pH and EC of suspension were analyzed using WENSAR multiparameter water quality meter (Model No. LMMP30). For the determination of soil organic matter content and carbonates, loss on ignition (LOI) at $550^{\circ} \mathrm{C}$ and $950^{\circ} \mathrm{C}$ method [54] was adopted. Bulk mineralogical analysis of selected soil samples was done using XRD. Major oxides $\left(\mathrm{SiO}_{2}, \mathrm{TiO}_{2}, \mathrm{Al}_{2} \mathrm{O}_{3}, \mathrm{FeO}, \mathrm{MnO}\right.$, $\mathrm{MgO}, \mathrm{CaO}, \mathrm{Na}_{2} \mathrm{O}, \mathrm{K}_{2} \mathrm{O}$, and $\mathrm{P}_{2} \mathrm{O}_{5}$ ) and some trace elements $(\mathrm{Ba}, \mathrm{Rb}, \mathrm{Sr}, \mathrm{V}, \mathrm{Zr}$ ) were analyzed using $\mathrm{X}$-ray fluorescence (WD-XRF), to study geochemistry of the study area, correlate them with toxic trace metals, and delineate sources of these trace metals i.e. geogenic or anthropogenic.

For the determination of $\mathrm{Co}, \mathrm{Cr}, \mathrm{Cu}, \mathrm{Ni}, \mathrm{Pb}$, and $\mathrm{Zn}$ in the soil sample, an open acid digestion method was followed. The method uses a combination of concentrated mineral acids i.e., $\mathrm{HF}, \mathrm{HNO} 3, \mathrm{H} 2 \mathrm{SO} 4$, and $\mathrm{HClO} 4$, in three steps [51]. The digested samples were analyzed for different metals using Atomic Absorption Spectrometer (AAS). To maintain precision and accuracy of heavy metal $(\mathrm{Co}, \mathrm{Cr}, \mathrm{Cu}, \mathrm{Ni}, \mathrm{Pb}$,

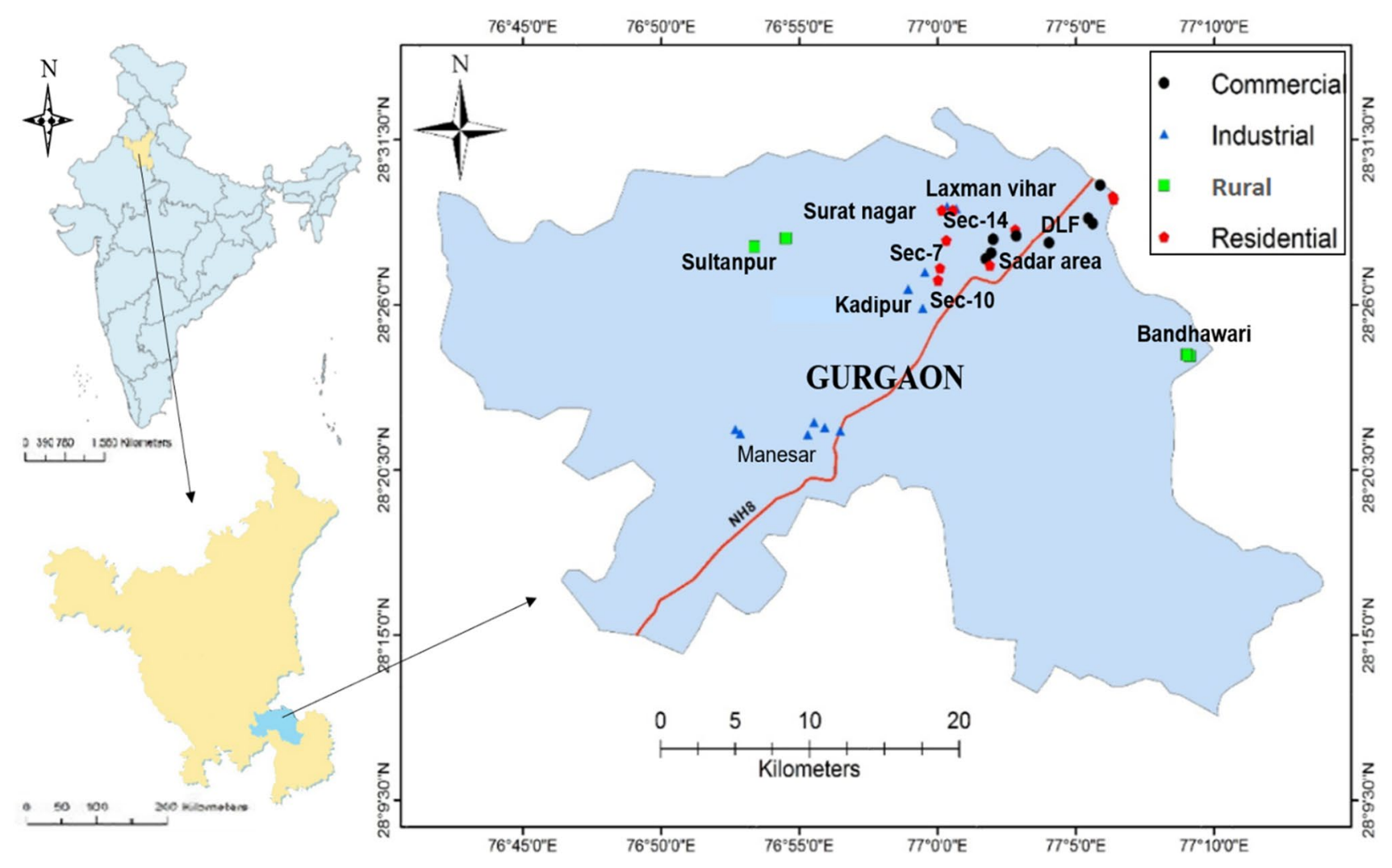

Fig. 1 Map of sampling locations over the study area in Gurugram 
Table 1 Description of sampling sites across the study area

\begin{tabular}{|c|c|c|c|c|c|c|}
\hline S. no. & Sampling location & Sample code & Sample range & Latitude & Longitude & Sample type \\
\hline 1 & Bandhawari & GNB & GNB1-GNB7 & $28^{\circ} 24^{\prime} 16.32^{\prime \prime} \mathrm{N}$ & $77^{\circ} 9^{\prime} 6.42^{\prime \prime} \mathrm{E}$ & $\mathrm{N}$ \\
\hline 2 & DLF area & GCD & GCD1-GCD6 & $28^{\circ} 28^{\prime} 42.34^{\prime \prime} \mathrm{N}$ & $77^{\circ} 5^{\prime} 33.35^{\prime \prime} \mathrm{E}$ & $\mathrm{C}$ \\
\hline 3 & IMT Manesar & GIM & GIM1-GIM6 & $28^{\circ} 22^{\prime} 7.39^{\prime \prime} \mathrm{N}$ & $76^{\circ} 54^{\prime} 33.47^{\prime \prime} \mathrm{E}$ & I \\
\hline 4 & Kadipur & GIK & GIK1-GIK3 & $28^{\circ} 26^{\prime} 56.52^{\prime \prime} \mathrm{N}$ & $76^{\circ} 59^{\prime} 32.60^{\prime \prime} \mathrm{E}$ & I \\
\hline 5 & Laxman Vihar & GRL & GRL1-GRL2 & $28^{\circ} 29^{\prime} 9.02^{\prime \prime} \mathrm{N}$ & $77^{\circ} 0^{\prime} 33.28^{\prime \prime} \mathrm{E}$ & $\mathrm{R}$ \\
\hline 6 & Sadar Area & GCSD & GCSD1-GCSD3 & $28^{\circ} 27^{\prime} 31.81^{\prime \prime} \mathrm{N}$ & $77^{\circ} 1^{\prime} 56.44^{\prime \prime} \mathrm{E}$ & $\mathrm{C}$ \\
\hline 7 & Sector-10 & GR10S & GR10S1-GR10S2 & $28^{\circ} 27^{\prime} 14.24^{\prime \prime} \mathrm{N}$ & $77^{\circ} 0^{\prime} 5.86^{\prime \prime} \mathrm{E}$ & $\mathrm{R}$ \\
\hline 8 & Sector-14 & GR14S & GR14S1-GR14S2 & $28^{\circ} 28^{\prime} 17.91^{\prime \prime} \mathrm{N}$ & $77^{\circ} 2^{\prime} 50.83^{\prime \prime} \mathrm{E}$ & $\mathrm{R}$ \\
\hline 9 & Sector-29 & GCD7 & GCD7 & $28^{\circ} 28^{\prime} 3.25^{\prime \prime} \mathrm{N}$ & $77^{\circ} 4^{\prime} 2.08^{\prime \prime} \mathrm{E}$ & C \\
\hline 10 & Sector-7 & GR7S & (GR7S:1-GR7S:2) & $28^{\circ} 27^{\prime} 52.30^{\prime \prime} \mathrm{N}$ & $77^{\circ} 0^{\prime} 30.44^{\prime \prime} \mathrm{E}$ & $\mathrm{R}$ \\
\hline 11 & Sultanpur & GNST & (GNST1,2,5,6) & $28^{\circ} 27^{\prime} 58.89^{\prime \prime} \mathrm{N}$ & $76^{\circ} 54^{\prime} 1.88^{\prime \prime} \mathrm{E}$ & $\mathrm{N}$ \\
\hline 12 & Surat Nagar & GRSR & (GRSR1-GRSR2) & $28^{\circ} 29^{\prime} 11.19^{\prime \prime} \mathrm{N}$ & $77^{\circ} 0^{\prime} 15.32^{\prime \prime} \mathrm{E}$ & $\mathrm{R}$ \\
\hline
\end{tabular}

$N$ rural, I industrial; C commercial, $R$ residential

and $\mathrm{Zn}$ ) analysis, the certified reference materials, JSD1, JSD2 (Geological Survey of Japan), and GSP2 (United States Geological Survey), were used for both AAS and XRF. For AAS the standards were digested along with the samples following the same procedure. A sample blank was also prepared with every batch digested. All the standards and sample blank were run with each batch of replicated samples in the course of analysis. An error of $5-10 \%$ was obtained between standards and its published values. The values for standards were within the $\%$ recovery range of 80-105. Also, E-Merck single element standards for different elements were serially diluted using Milli-Q to obtain a working standard for preparing calibration curve. The relative standard deviation for sample replicates lies within the range of $5 \%$. The analytical data obtained were consistent with the international reference standards.

\subsection{Statistical analysis and index calculation}

PCA, correlation, and soil pollution indices (Igeo, EF, CF, and $\mathrm{PLI}$ ) were used to analyze results. Soil pollution indices are discussed below. Pearson's correlation and PCA were carried out using SPSS ( $v$ 20.0) to identify the sources of heavy metals in soils. Geochemical distribution maps for $\mathrm{Co}, \mathrm{Cr}, \mathrm{Cu}, \mathrm{Ni}, \mathrm{Pb}$, and $\mathrm{Zn}$ were generated by the most widely used interpolation method, i.e. inverse distance weighting (IDW) method using GIS (Arc Map 10.2).

\subsubsection{Geo-accumulation index (Igeo)}

Geo-accumulation index is a qualitative method introduced by Muller [41] for metal pollution assessment. It is expressed as:
Igeo $=\log _{2}\left(\frac{C n}{1.5 B n}\right)$

where $\mathrm{Cn}$ represents the concentration of metal(s) in the samples, and $\mathrm{Bn}$ is the geochemical background value of element " $n$ " soil. The natural lithogenic variations were corrected by introducing a background matrix correction factor of 1.5. Thus, calculated Igeo values are categorized into seven classes by Muller [41], depending on the numerical value of the index. Each class represents different levels of pollution in the study area (Table 4). In the present study, upper continental crust (UCC) [40] values were considered as background to calculate the Igeo.

\subsubsection{Enrichment factor (EF)}

Metals enter the soil from a variety of sources, which may include natural parent material and some exogenous sources. In general, the exogenous sources are anthropogenic in nature. Enrichment factors can estimate these anthropogenic inputs. Though different approaches are used in different studies to calculate EF, we used normalization method in this study. In this method, EF is calculated by dividing its concentration ratio with the chosen normalizing elements by the same ratio calculated in the selected background [20,32].

$\mathrm{EF}=\frac{\mathrm{Cs} / \mathrm{NEs}}{\mathrm{Cb} / \mathrm{NEb}}$

where Cs and NEs are the concentration of the metal and the normalizing element in the samples, respectively, and $\mathrm{C}_{\mathrm{b}}$ and $\mathrm{NE}_{\mathrm{b}}$ represent their concentrations of the same metal and same normalizing element respectively, in the selected background. The most commonly used normalizing elements are $\mathrm{Al}, \mathrm{Fe}$, and $\mathrm{Ti}$ due to their consistent 
behavior. In this study, Fe was selected as a normalizing element. UCC values of major oxides and trace elements of McLennan [40] were used as background values. EF is categorized into seven classes [15], which are used to show enrichment status (Table 4).

\subsubsection{Contamination factor (CF) and pollution load index (PLI)}

Another parameter used for the assessment of soil pollution is the Contamination factor $[23,62]$ and PLI given by [59]. CF is an important tool in assessing the level of contamination by individual metal It is calculated as a quotient obtained by dividing the concentration of metal with some background concentration. In this study, we have used UCC as background.

$\mathrm{CF}=\frac{\mathrm{Cm}}{\mathrm{Cb}}$

where $\mathrm{CF}$ is the contamination factor, $\mathrm{Cm}$ is the concentration of metal in the sample, and $\mathrm{Cb}$ is the background concentration of that metal. Contamination values are categorised into four classes by Hakanson [23] (Table 4).

PLI can be defined as the geometric mean of the values of the contamination factor for each site.

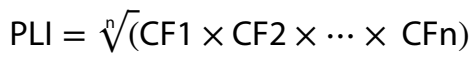

In this study, UCC [40] is used as background concentration. The pollution load index (PLI) provides simple but comparative means for the determination of the quality of a site. The quality of a site can be described according to the following criteria: where a value of $\mathrm{PLI}<1$ denotes perfection; $P L I=1$ indicates only baseline levels of pollutants, and PLI $>1$ would indicate deterioration of site quality [59].

\subsubsection{Non-carcinogenic- health risk assessment (NC-HRA)}

Daily exposure to toxic metals present in soil poses a threat to human body systems $[1,56]$. These metals can enter the body through three main pathways: ingestion, inhalation or dermal contact and cause adverse effects in adults as well as children [19]. A majority of samples were collected from parks and open lands, that are in close proximity to residents, studying HRA become an important risk assessment tool. In this study, non-carcinogenic health risk was assessed using the USEPA method $[36,65]$ which is the most effective and widely used method. According to USEPA framework, in this complex and multistep procedure, first step is the calculation of exposure dose. Based on this Chronic daily intake (CDI) or average daily dose (ADD) for different routes- inhalation, ingestion and dermal contact, is calculated using equations:

$$
\begin{aligned}
& C D I_{\text {ing-nc }}=\frac{\left[C^{*} \mid R^{*} E F^{*} E D\right]}{\left[B W^{*} A T n c\right]} * 10^{-6} \\
& C D I_{\text {inh-nc }}=\frac{\left[C^{*} E F^{*} E T^{*} E D\right]}{\left[P E F^{*} 24^{*} A T n c\right]} \\
& C D I_{\text {der-nc }}=\frac{\left[C^{*} \mathrm{SA}^{*} A F^{*} A B s d^{*} E F^{*} E D\right]}{\left[B W^{*} A T n c\right]} * 10^{-6}
\end{aligned}
$$

$\mathrm{CDI}_{\text {ing-nc' }} \mathrm{CDI}_{\text {inh-nc }}$ and $\mathrm{CDI}_{\text {der-nc, }}$ is the Chronic daily intake or average daily dose contacted through ingestion $(\mathrm{mg} /$ $\mathrm{kg} /$ day), inhalation of $\left(\mathrm{mg} / \mathrm{m}^{3}\right)$, and dermal contact $(\mathrm{mg} /$ $\mathrm{kg} /$ day) respectively, with soil particles, respectively. $C$ is the concentration of metal in soil. The values of variables used for assessment of risk and their detailed description is given in Table 6. The next step is the calculation of $\mathrm{HQ}$ (Hazard Quotient), followed by HI (Hazard Index). Once CDI is calculated, based on the non-carcinogenic risk, a Hazard quotient $(\mathrm{HQ})$ is calculated using the equation:

$\mathrm{HQi}=\frac{\mathrm{CDli}_{\mathrm{nc}}}{\mathrm{RfDi}}$

Each metal is assigned a different RfD value for ingestion, inhalation, and dermal pathway. RfD values for different metals are given in Table 6. Hazard Quotient above 1 reflects possible adverse health effects, whereas lower than 1 means no adverse health effects [67]. A summation of three $\mathrm{HQ}$ values for metal then provides its hazard Index.

$\mathrm{HI}=\sum \mathrm{HQi}=\sum \frac{\mathrm{CDli}_{\mathrm{nc}}}{\mathrm{RfDi}}$

$\mathrm{HI}$ value is considered as the total non-carcinogenic risk provided by a metal. The value of $\mathrm{HI} \leq 1$ indicates "no significant risk" of non-carcinogenic effects whereas $\mathrm{HI}>1$ indicates probability of non-carcinogenic effects [65].

\section{Results and discussion}

\subsection{Determination of $\mathrm{pH}$, electrical conductivity (EC) and organic matter (OM)}

The results of soil quality parameters like $\mathrm{pH}, \mathrm{EC}$, organic matter, major oxides, and trace elements have been presented in Table 2. The soils of Gurugram are sandy (75-85 wt\%) similar to that reported in earlier studies [14, 37]. The average values of $\mathrm{pH}$ are 7.6, 7.3, 7.4, and 7.3 in rural, industrial, commercial and residential soils, respectively, which indicate its alkaline nature. In general, soils of arid and semiarid regions are alkaline due to the decrease in leaching of cation, released by mineral weathering, 
Table 2 Average $\mathrm{pH}$, electrical conductivity $(\mathrm{EC})(\mu \mathrm{S} / \mathrm{cm})$, organic matter $(\mathrm{OM})(\%)$, major oxides (wt\%), LOI and trace metals (mg/kg) in soils of Gurugram

\begin{tabular}{|c|c|c|c|c|c|c|c|c|c|c|c|c|c|c|c|c|}
\hline & \multicolumn{4}{|c|}{ Rural $(n=7)$} & \multicolumn{4}{|c|}{ Industrial $(n=9)$} & \multicolumn{4}{|c|}{ Commercial $(n=10)$} & \multicolumn{4}{|c|}{ Residential $(n=10)$} \\
\hline & Mean & Min & Max & SE & Mean & Min & Max & SE & Mean & Min & Max & SE & Mean & Min & Max & SE \\
\hline $\mathrm{pH}$ & 7.6 & 6.6 & 8.8 & 0.4 & 7.3 & 6.9 & 7.5 & 0.1 & 7.5 & 7.1 & 7.9 & 0.1 & 7.3 & 6.8 & 7.9 & 0.1 \\
\hline EC & 87.04 & 20.50 & 153.50 & 15.71 & 92.48 & 57.10 & 225.00 & 17.41 & 122.58 & 77.70 & 215.00 & 13.61 & 328.88 & 73.60 & 1698.00 & 165.25 \\
\hline OM & 1.61 & 0.81 & 2.49 & 0.21 & 1.87 & 1.11 & 2.81 & 0.18 & 2.59 & 1.61 & 4.39 & 0.33 & 3.16 & 1.80 & 4.66 & 0.31 \\
\hline $\mathrm{Al}_{2} \mathrm{O}_{3}$ & 11.55 & 10.54 & 12.45 & 0.23 & 11.19 & 9.66 & 12.74 & 0.30 & 11.55 & 9.17 & 12.47 & 0.32 & 11.57 & 9.60 & 13.02 & 0.44 \\
\hline $\mathrm{CaO}$ & 3.52 & 1.33 & 9.38 & 1.12 & 2.00 & 1.38 & 2.72 & 0.16 & 2.94 & 1.46 & 5.21 & 0.37 & 2.73 & 1.53 & 7.08 & 0.57 \\
\hline $\mathrm{FeO}$ & 3.19 & 2.34 & 4.10 & 0.25 & 3.15 & 2.58 & 3.64 & 0.12 & 3.40 & 2.91 & 3.76 & 0.09 & 3.33 & 2.79 & 3.93 & 0.13 \\
\hline $\mathrm{K}_{2} \mathrm{O}$ & 1.93 & 1.63 & 2.31 & 0.10 & 1.99 & 1.85 & 2.17 & 0.04 & 2.04 & 1.74 & 2.16 & 0.04 & 2.10 & 1.89 & 2.39 & 0.06 \\
\hline $\mathrm{MgO}$ & 1.51 & 0.73 & 2.51 & 0.28 & 1.57 & 1.21 & 2.01 & 0.10 & 1.79 & 1.39 & 2.12 & 0.09 & 1.83 & 1.27 & 2.17 & 0.10 \\
\hline $\mathrm{MnO}$ & 0.05 & 0.05 & 0.07 & 0.00 & 0.06 & 0.05 & 0.06 & 0.00 & 0.06 & 0.05 & 0.06 & 0.00 & 0.06 & 0.06 & 0.06 & 0.00 \\
\hline $\mathrm{Na}_{2} \mathrm{O}$ & 1.36 & 1.17 & 1.64 & 0.06 & 1.41 & 1.25 & 1.72 & 0.05 & 1.18 & 1.04 & 1.25 & 0.02 & 1.25 & 0.99 & 1.88 & 0.08 \\
\hline $\mathrm{P}_{2} \mathrm{O}_{5}$ & 0.14 & 0.10 & 0.20 & 0.01 & 0.15 & 0.08 & 0.18 & 0.01 & 0.18 & 0.10 & 0.34 & 0.02 & 0.21 & 0.12 & 0.31 & 0.02 \\
\hline $\mathrm{SiO}_{2}$ & 71.74 & 63.17 & 79.49 & 2.03 & 72.98 & 69.29 & 77.96 & 0.97 & 69.53 & 65.99 & 73.31 & 0.96 & 70.62 & 67.50 & 74.00 & 0.67 \\
\hline $\mathrm{TiO}_{2}$ & 0.50 & 0.41 & 0.68 & 0.04 & 0.56 & 0.46 & 0.69 & 0.02 & 0.57 & 0.49 & 0.64 & 0.02 & 0.57 & 0.48 & 0.64 & 0.02 \\
\hline LOI & 3.60 & 2.23 & 5.29 & 0.44 & 3.01 & 1.81 & 3.90 & 0.22 & 4.17 & 3.02 & 5.58 & 0.27 & 4.07 & 2.30 & 6.05 & 0.36 \\
\hline $\mathrm{Ba}$ & 337.27 & 320.08 & 382.29 & 8.84 & 408.65 & 325.57 & 781.85 & 47.67 & 371.72 & 343.78 & 394.82 & 5.76 & 365.89 & 296.50 & 416.00 & 10.16 \\
\hline $\mathrm{Cd}$ & 5.65 & 3.72 & 6.58 & 0.37 & 6.43 & 6.02 & 6.91 & 0.12 & 5.94 & 5.16 & 6.42 & 0.12 & 6.27 & 5.95 & 6.57 & 0.07 \\
\hline Co & 5.82 & 2.54 & 10.18 & 1.08 & 6.58 & 2.54 & 12.50 & 0.98 & 7.65 & 2.68 & 12.10 & 0.88 & 12.58 & 5.56 & 27.64 & 2.45 \\
\hline $\mathrm{Cr}$ & 80.21 & 56.82 & 93.88 & 4.47 & 83.62 & 65.02 & 99.06 & 3.42 & 90.46 & 72.98 & 105.52 & 3.62 & 86.06 & 58.60 & 139.16 & 7.40 \\
\hline $\mathrm{Cu}$ & 23.28 & 16.50 & 33.20 & 2.29 & 21.23 & 17.20 & 27.98 & 1.24 & 29.72 & 19.24 & 59.04 & 3.89 & 30.90 & 16.98 & 51.28 & 3.69 \\
\hline $\mathrm{Ni}$ & 29.71 & 16.39 & 49.35 & 4.46 & 25.01 & 17.69 & 34.33 & 1.96 & 29.83 & 25.35 & 34.51 & 1.07 & 28.23 & 18.81 & 36.33 & 1.96 \\
\hline $\mathrm{Pb}$ & 17.67 & 15.50 & 20.56 & 0.81 & 18.38 & 13.00 & 31.08 & 1.84 & 29.26 & 15.50 & 63.56 & 6.12 & 21.64 & 16.28 & 28.20 & 1.43 \\
\hline $\mathrm{Rb}$ & 89.41 & 73.22 & 112.46 & 4.78 & 95.74 & 86.46 & 108.59 & 2.61 & 99.54 & 84.99 & 107.60 & 2.01 & 99.77 & 80.92 & 110.88 & 3.34 \\
\hline $\mathrm{Sr}$ & 205.40 & 179.68 & 228.60 & 6.54 & 194.18 & 178.06 & 209.84 & 3.44 & 195.99 & 174.15 & 225.49 & 5.70 & 203.62 & 182.74 & 254.50 & 7.82 \\
\hline V & 58.23 & 41.32 & 98.80 & 7.77 & 60.40 & 48.55 & 72.62 & 2.60 & 65.89 & 55.74 & 75.75 & 2.22 & 63.61 & 52.69 & 72.80 & 2.38 \\
\hline $\mathrm{Zn}$ & 67.13 & 50.62 & 85.28 & 4.51 & 77.33 & 52.28 & 142.04 & 8.86 & 112.52 & 59.90 & 231.80 & 16.18 & 105.14 & 61.70 & 142.38 & 8.53 \\
\hline $\mathrm{Zr}$ & 310.25 & 255.66 & 408.66 & 19.51 & 336.26 & 277.49 & 543.76 & 27.45 & 341.83 & 295.01 & 407.45 & 13.63 & 324.87 & 274.30 & 507.37 & 22.53 \\
\hline
\end{tabular}

SE standard error

under dry conditions [8]. Kahn et al. [29], in their studies have confirmed the correlation of $\mathrm{pH}$ with trace metals and its effect on mobility and bioavailability of trace metals. The alkaline nature of soil decreases the dissolution of metals and thus affects their concentration. Electrical conductivity (EC) in commercial $(123 \mu \mathrm{S} / \mathrm{cm})$ and residential $(329 \mu \mathrm{S} / \mathrm{cm})$ soils has almost double the value that is observed in industrial $(93 \mu \mathrm{S} / \mathrm{cm})$ and rural $(87 \mu \mathrm{S} / \mathrm{cm})$ soils. High EC in residential soils indicates the presence of contamination. OM content in the soils has a relatively high mean value at the residential site (3.24 wt\%), followed by a commercial site $(2.51 \mathrm{wt} \%)$. The observed relatively high values of organic matter in residential and commercial soils in comparison to rural soils $(1.61 \%)$ may be attributed to aerial organic pollutants (coal particles, soot, and other products of incomplete combustion of solid and liquid fuel) [50] and increased productivity in parkland areas [68] while sampling points in rural areas were mainly barren with minimal productivity. Soil OM reduces metal bioavailability and mobility and promotes its retention [72]. The results of various parameters of all the samples are given in Table 1S (provided in the supplementary file).

\subsection{Determination of major oxides and trace metals}

Geochemical data on major and trace elements obtained from the soil samples from Gurugram are shown in Table 2 . The major oxides concentration is pretty similar in all the land uses. Among major oxides, the soils studied from Gurugram soil consist dominantly of $\mathrm{SiO}_{2}$ (approx. $70 \mathrm{wt} \%$ ), $\mathrm{Al}_{2} \mathrm{O}_{3}$ (11.5 wt\%) and $\mathrm{FeO}$ (approx. $\left.3.2 \mathrm{wt} \%\right)$. The average concentration of $\mathrm{CaO}$ in rural, industrial, commercial and residential soils is $3.52,2.00,2.94$ and $2.73 \%$, respectively. The obtained geochemical data correlates well with minerals present in the surface soils of Gurugram. Common alumino-silicate minerals such as quartz, K-feldspar, muscovite and sodic plagioclase are abundant in the samples. A significant amount of $\mathrm{CaO}$ samples could be attributed 
to the presence of calcite mineral. However, variable concentrations of $\mathrm{CaO}$ in different land-use areas could be due to anthropogenic sources such as cement from construction activities in the residential areas.

Various studies have investigated the concentration of trace metals in urban soils across the globe and have concluded that the concentration of these metals is higher in urban soils compared to rural areas $[5,34,49,57,61]$. The $19^{\text {th }}$ element of the earth crust, $V$ is naturally present in soils in igneous and metamorphic rocks $[60,69]$ or it may come from various industrial activities e.g. electronics, textile dyeing, and metallurgy etc. It is also a common constituent of residual and fuel oils [55]. $\mathrm{V}$ is observed to show a mean value of $58.23,60.40,65.89$ and $63.61 \mathrm{mg} / \mathrm{kg}$ in rural, industrial, commercial and residential soils, respectively. The values are below WHO (1996) permissible limits of soil for $V(100 \mathrm{mg} / \mathrm{kg})$ [30]. A major concern of $V$ toxicity is in cities with alkaline soil [25].

Sr concentrations in soil are strongly controlled by parent rocks. It easily gets mobilised during the weathering process and gets trapped in clay minerals and is strongly fixed by organic matter [60]. The average concentration of $\mathrm{Sr}$ in the region is 195.99, 194.18, 195.99, and $203 \mathrm{mg} /$ $\mathrm{kg}$ in rural, industrial, commercial and residential soils, respectively. Uniform average concentrations of $\mathrm{Sr}$ in all the sites indicate its geogenic origin. Sr is found associated with Kankar and limestone [30], which is dominantly found in Gurugram. The average concentration of $\mathrm{Sr}$ in all the soils approach WHO permissible limit of $200 \mathrm{mg} / \mathrm{kg}$. The higher concentrations of $\mathrm{Zr}$ might be from zircon-bearing aeolian sediments from the Thar Desert, in addition to parent rocks of soil [60]. The average concentration of $\mathrm{Zr}$ in the region is $310.25,336.26,341.25$, and $324.87 \mathrm{mg} / \mathrm{kg}$ in rural, industrial, commercial and residential soils, respectively. Uniformity in concentration indicates its sources to be geogenic.

Feldspar weathering in silicate rocks may be the source of the high concentration of $\mathrm{Ba}$ [22]. Whereas concentration of $\mathrm{Rb}$ is mainly associated with K-feldspar, mica and clay minerals and its behaviour in soil is primarily controlled by adsorption on the surface of clay minerals as well as organic matter [27]. The uniformity in average Ba and $\mathrm{Rb}$ concentration indicates its geogenic origin.

Co reaches the soil from both natural as well as anthropogenic sources and is less toxic in alkaline soil than in acidic soil [39]. The average concentration of Co in rural, industrial, commercial and residential soils is found to be $5.82,6.58,7.65$ and $12.58 \mathrm{mg} / \mathrm{kg}$. Residential soils have Co values almost double the concentration in rural soils. Soils from all the land uses show Co values below WHO permissible limit of $17 \mathrm{mg} / \mathrm{kg}$. Such low values of Co are due to soil alkalinity due to which Co cannot be derived much from natural rocks.
Although $\mathrm{Cr}$ in these soils is naturally present, very high concentrations of $\mathrm{Cr}$ in urban soils is attributed to improper disposal of waste containing $\mathrm{Cr}$ such as plastic packaging and $\mathrm{Pb}-\mathrm{Cr}$ batteries, paint, catalytic manufacturing, and electroplating cleaning, etc. [5]. $\mathrm{Cr}$ is uniformly distributed at all the sites. The average concentration of $\mathrm{Cr}$ in studied soils is $80.21,83.62,90.46$ and $86.06 \mathrm{mg} /$ $\mathrm{kg}$ in rural, industrial, commercial and residential soils, respectively and all the values are well below WHO limits of $100 \mathrm{mg} / \mathrm{kg}$ for $\mathrm{Cr}$.

$\mathrm{Cu}$ content in soil naturally comes from weathering of biotite, orthoclase, and plagioclase feldspars [27] while anthropogenic sources mainly include agriculture, waste dumping, steel manufacturing, and agrochemical production industry [73]. In soils, Cu is strongly held by OM and also it precipitates with sulphides, oxides and hydroxides which makes it immobile [4]. The average concentration of Cu in studied soils is $23.28,21.23,29.72$ and $30.90 \mathrm{mg} /$ $\mathrm{kg}$ in rural, industrial, commercial and residential soils, respectively. As the majority of landuse in Gurugram is agriculture this could be the reason for presence of $\mathrm{Cu}$ in urban soils (industrial, commercial and residential) similar to studies of Bretzel and Calderisi [9]. The average $\mathrm{Cu}$ concentration in all the soils is below WHO limit of $36 \mathrm{mg} /$ $\mathrm{kg}$. A low concentration of $\mathrm{Cu}$ is attributed to alkaline soils which reduce its availability [30].

Dust originated from weathering of rocks and soil in the natural sources of $\mathrm{Ni}$ [10]. Anthropogenic Sources include waste dumping of $\mathrm{Ni}-\mathrm{Cd}$ batteries, sewage water and use of Ni-based paint in the housing area etc. The average concentration of $\mathrm{Ni}$ in studied soils is $29.71,25.01,29.83$, $28.23 \mathrm{mg} / \mathrm{kg}$ in rural, industrial, commercial and residential soils, respectively. Similar values of $\mathrm{Ni}$ in all the landuses in comparison to rural soils suggest their sources to be natural which may be weathered rock material in windblown dust. The average $\mathrm{Ni}$ concentration in all the landuses is below WHO limit of $35 \mathrm{mg} / \mathrm{kg}$.

$\mathrm{Pb}$, a metal of serious concern, is non-degradable and toxic [49]. A major source of $\mathrm{Pb}$ in urban soils is gasoline additives. Although the use of $\mathrm{Pb}$ in gasoline in vehicles has been banned much before, traces emitted in the environment are still present due to its higher residence time [12]. Also, $\mathrm{Pb}$ from paints is a source of concern in urban soils. The average concentration of $\mathrm{Pb}$ in studied soils is $17.67,18.38,29.26$ and $21.64 \mathrm{mg} / \mathrm{kg}$ rural, industrial, commercial and residential soils, respectively. Commercial soils show highest $\mathrm{Pb}$ concentration of all four landuses. $\mathrm{Pb}$ Values are well below WHO permissible limits of $85 \mathrm{mg} / \mathrm{kg}$. Coal burning is a source of lead which is a natural practice in villages.

The average concentration of $\mathrm{Zn}$ in studied soils is $67.13,77.33,112.52$, and $105.14 \mathrm{mg} / \mathrm{kg}$ rural, industrial, commercial and residential soils, respectively. All the soils 
have an average concentration above WHO limits. The average concentration of $\mathrm{Zn}$ in commercial and residential soils is almost double the permissible limits of $50 \mathrm{mg} / \mathrm{kg}$. The high concentrations of $\mathrm{Zn}$ in all the sites above permissible limits indicate its sources to be anthropogenic and can be related to the wear-and-tear of vehicle components and brake pads in heavy traffic zones or fertilizer industry $[33,73]$. In rural soils, the sole reason can be vehicular emission influenced atmospheric fallout.

At the rural and industrial sites, the distribution follows the order $\mathrm{Co}<\mathrm{Pb}<\mathrm{Cu}<\mathrm{Ni}<\mathrm{Zn}<\mathrm{Cr}$. At commercial and residential sites, $\mathrm{Zn}$ gets enriched, and the order follows as $\mathrm{Co}<\mathrm{Cu}=\mathrm{Ni}=\mathrm{Pb}<\mathrm{Cr}<\mathrm{Zn}$. The average concentration of trace metals in soil samples at different land use areas of Gurugram is shown in Fig. 2. The average concentration of $\mathrm{Co}$ and $\mathrm{Cu}$ in residential soils, $\mathrm{Cr}$ in all the land uses, and $\mathrm{Zn}$ in commercial and residential soils are above world average soil value given by [4]. World average soil values
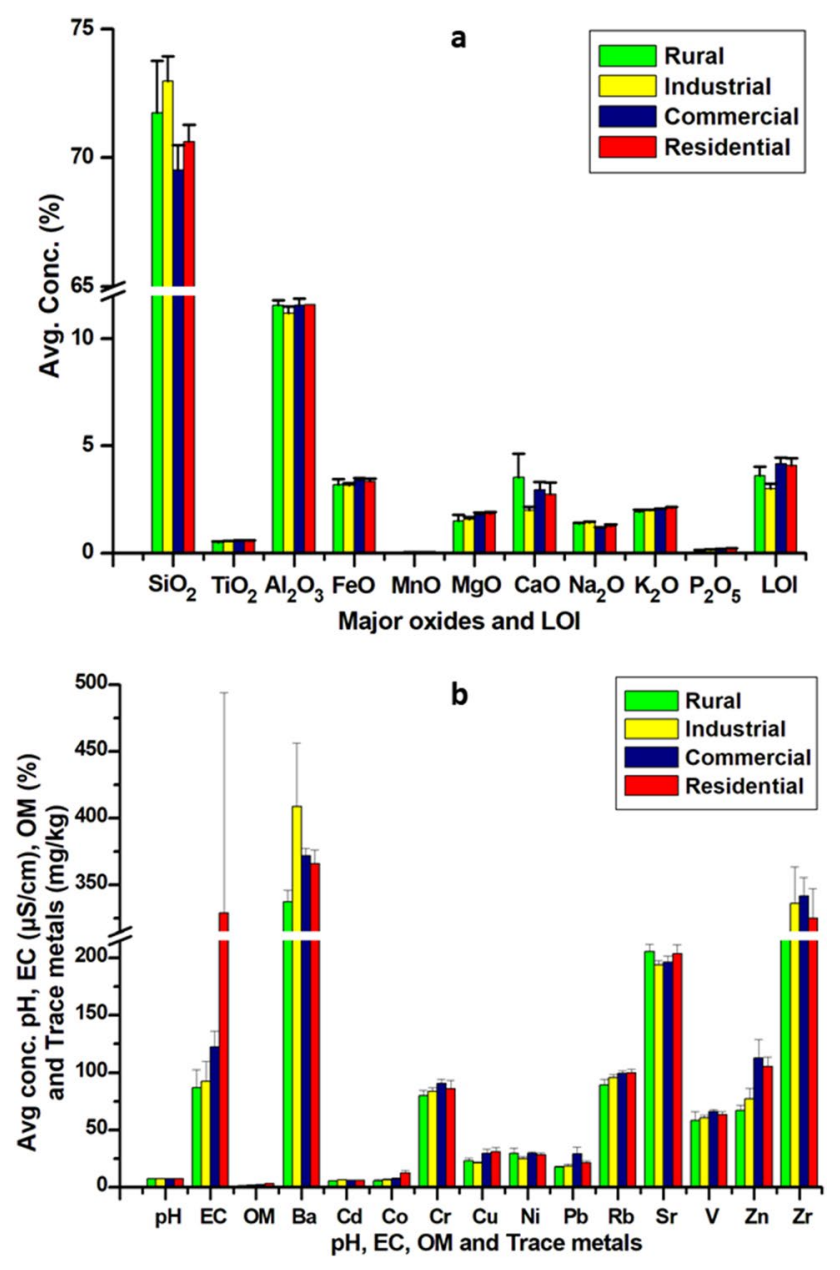

Fig. 2 Histogram showing the average concentrations of a $\mathrm{pH}$, EC $(\mu \mathrm{S} / \mathrm{cm}), \mathrm{OM}(\%)$ and trace metals $(\mathrm{mg} / \mathrm{kg})$; and $\mathbf{b}$ major oxides (wt\%) and LOI in soil samples at different landuse areas of Gurugram are given in Table 3. Different permiscible limits are highlighted in Table 3.

\subsection{Calculation of pollution indices}

\subsubsection{Geo-accumulation index (Igeo)}

Igeo is calculated using the criteria set by Muller [41]. As shown in Table 5, the calculated average Igeo values in the sediment samples of four land uses are $<1$ and fall under class 0 (uncontaminated) of Muller's classification (Table 4). However, few soil samples under these land use categories show Igeo values between 0-1 and fall under class 1 (uncontaminated to moderately contaminated) (Supplementary Table 1). These samples are GIK1 for Pb (0.29) and $\mathrm{Zn}(0.42)$ at industrial site. At commercial site, samples GCD1 for $\mathrm{Zn}(0.43), \mathrm{GCSD} 1$ for $\mathrm{Cu}(0.02)$ and $\mathrm{Zn}$ (0.52), GCSD2 for $\mathrm{Pb}(0.12)$ and GCSD3 for $\mathrm{Cu}(0.65)$ are uncontaminated to moderately contaminated. In residential soils, samples GR7S2 for $\mathrm{Cu}(0.13)$ and $\mathrm{Pb}(0.12)$, GR10S1 for Pb (0.42) and Zn (0.11), GRL1 for Co (0.12) and $\mathrm{Pb}(0.41)$ and $\mathrm{GRL} 2$ for $\mathrm{Cr}(0.16), \mathrm{Cu}(0.45), \mathrm{Pb}(0.14)$ and $\mathrm{Zn}$ (0.15) fall under category 1 . Also, some samples, GCSD1 for $\mathrm{Pb}$ (1.28) and GCSD3 for $\mathrm{Pb}$ (1.32) and $\mathrm{Zn}$ (1.12), are moderately contaminated (class 2 ). The variations in Igeo values for different trace metals in soils from different landuse of Gurugram are depicted in Box Plots (Fig. 3). Based on the calculated Igeo values of selected samples, soils of Gurugram are uncontaminated.

\subsubsection{Contamination factor (CF) and pollution load index (PLI)}

According to Hakanson [23] classification (Table 4), average contamination factor values (Table 5 ) suggest moderate contamination of $\mathrm{Cr}$ in all the four land uses $(\mathrm{Cr}>1)$. Whereas $\mathrm{Cu}$ contamination is low $(\mathrm{CF}<1)$ in rural $(0.84)$ and industrial $(0.84)$ soil and moderate $(\mathrm{CF}<1)$ in commercial (1.17) and residential (1.19) soil. Co and Ni show low contamination according to CF criteria set by Hakanson [23]; on the other hand, $\mathrm{Pb}$ and $\mathrm{Zn}$ show moderate contamination in industrial (1.05 and 1.07), commercial (1.75 and 1.56) and residential soils (1.22 and 1.42). In general, soils show moderate contamination.

Pollution load index (PLI) at rural, industrial commercial and residential sites ranges from 0.43 to $1.07,0.62-1.01$, $0.76-1.33$ and $0.66-1.44$ respectively. Average values of $\mathrm{PLI}<1$ indicate all four sites show perfection according to criteria set by Tomlinson et al. [59]. However, one sample in industrial sites (GIK1), one sample in commercial sites (GCSD3), and almost $50 \%$ of the samples in residential soils show PLI > 1 and indicate baseline pollution. 


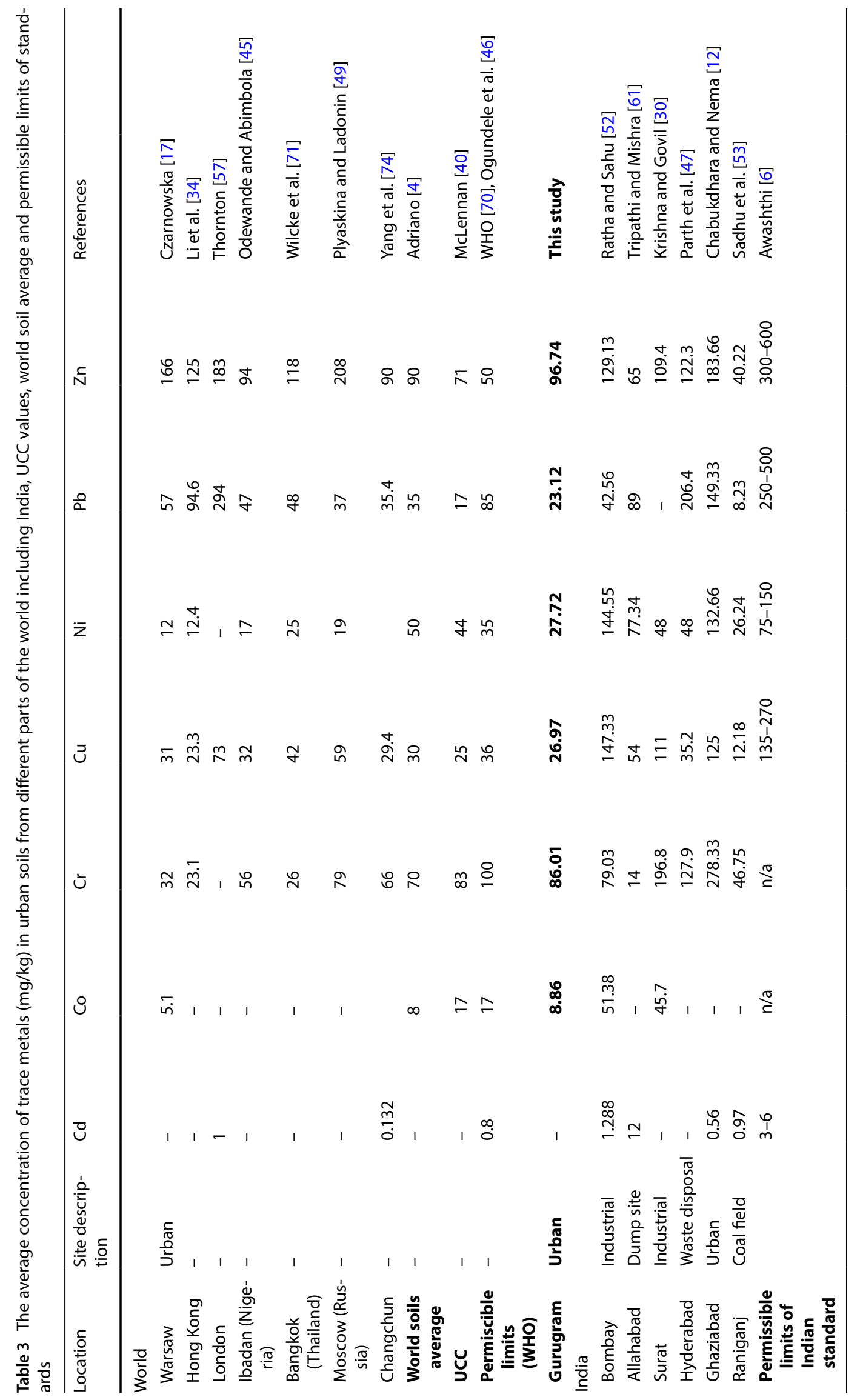


Table 4 Contamination categories based on Igeo [41], EF [15] and PLI [59] categorization

\begin{tabular}{|c|c|c|c|c|c|}
\hline Class & Value & Level of Contamination & Level & Value & Categorisation \\
\hline $\begin{array}{l}\text { Geoac- } \\
\text { cul- } \\
\text { mula- } \\
\text { tion } \\
\text { Index } \\
{[41]}\end{array}$ & & & Enrich & & \\
\hline 0 & $<0$ & Uncontaminated & I & $\mathrm{EF}<1$ & No enrichment \\
\hline 1 & $>0$ to $<1$ & $\begin{array}{l}\text { Uncontaminated to moderately contami- } \\
\text { nated }\end{array}$ & II & $E F=>1$ to $<3$ & Minor enrichment \\
\hline 2 & $>1$ to $<2$ & Moderately contaminated & III & $E F=>3$ to $<5$ & Moderate enrichment \\
\hline 3 & $>2$ to $<3$ & Moderately to strongly contaminated & IV & $\mathrm{EF}=>5$ to $<10$ & Moderately severe enrichment \\
\hline 4 & $>3$ to $<4$ & Strongly contaminated & V & $\mathrm{EF}=>10$ to $<25$ & Severe enrichment \\
\hline 5 & $>4$ to $<5$ & Strongly to extremely contaminated & $\mathrm{VI}$ & $\mathrm{EF}=>25$ to $<50$ & Very severe enrichment \\
\hline 6 & $>5$ & Extremely strongly contaminated & VII & $E F>50$ & Extremely severe enrichment \\
\hline \multicolumn{3}{|c|}{ Contamination factor [23] } & \multicolumn{3}{|c|}{ Pollution load index [59] } \\
\hline 1 & $\mathrm{cf}<1$ & Low contamination & 1 & $\mathrm{PLI}<1$ & Perfection \\
\hline 2 & $1<\mathrm{cf}<3$ & Moderate contamination & 2 & $\mathrm{PLI}=1$ & Baseline levels of pollutants \\
\hline 3 & $3<\mathrm{cf}<6$ & Considerable contamination & 3 & PLI> 1 & Deterioration of site quality \\
\hline 4 & $c f>6$ & Very high contamination & & & \\
\hline
\end{tabular}

\subsubsection{Enrichment factor (EF)}

UCC values are used to determine enrichment factors [15]. Among the major element composition of the studied samples, irrespective of the land-use pattern, $\mathrm{SiO}_{2}$ shows slight enrichment compared to that of crustal average, whereas all other major elements show different levels of depletion, $\mathrm{Na}_{2} \mathrm{O}$ being most depleted $\left(\mathrm{SiO}_{2}>\mathrm{MnO}\right.$ $=\mathrm{TiO}_{2}>\mathrm{P}_{2} \mathrm{O}_{5}>\mathrm{Al}_{2} \mathrm{O}_{3}=\mathrm{FeO}=\mathrm{MgO}>\mathrm{K}_{2} \mathrm{O}>\mathrm{Na}_{2} \mathrm{O}$ ). Among trace elements ( $\mathrm{Ba}, \mathrm{Sr}, \mathrm{V}, \mathrm{Zr}$, and $\mathrm{Rb}$ ), only $\mathrm{Zr}$ with average concentration $>1 \mathrm{mg} / \mathrm{kg}$ is found to be enriched in soils from all the land uses.

The average $\mathrm{EF}$ values for various toxic trace metals soils of Gurugram show minor enrichment for $\mathrm{Cr}, \mathrm{Cu}, \mathrm{Pb}$, and $\mathrm{Zn}$ while no enrichment for $\mathrm{Co}$ and $\mathrm{Ni}$ according to criteria set by Chen et al. [15]. The average EF values are 1.49, 1.44, $1.42,1.41$ and $1.22,1.20,1.58,1.62$ at rural, industrial, commercial, and residential sites for $\mathrm{Cu}$ and $\mathrm{Cr}$, respectively. The highest enrichment fo $\mathrm{Pb}$ is observed in commercial soils with an average value of 2.3 for EF. Enrichment of $\mathrm{Pb}$ in rural soils (1.47) is of particular concern. The observed high concentration of $\mathrm{Pb}$ at rural sites, particularly Sultanpur village, may be due to the presence of Sultanpur bird sanctuary, which is a major tourist place. The regular movement of heavy vehicles related to maintenance and tourism may be the reason for observed higher $\mathrm{Pb}$ contents. The high value of $\mathrm{Pb}$ at commercial and residential sites is attributable to the massive use of $\mathrm{Pb}$-based paints and high traffic activities. The average EF values for $\mathrm{Zn}$ are $1.28,1.52,2.11$ and 1.94 at rural, industrial, commercial and residential sites, respectively. High enrichment of $\mathrm{Zn}$ at commercial sites may be attributed to vehicular sources only. The results indicate that soils of Gurugram show no enrichment for $\mathrm{Co}$ and $\mathrm{Ni}$ with values $<1$ (Fig. 4). Two commercial sites (GSD1 and GSD3) show moderate enrichment for $\mathrm{Pb}$ with values between 3-5 according to criteria set by Chen et al. [15]. The EF values $>1$ indicate the influence of anthropogenic inputs to soils (Table 6).

\subsubsection{Non-carcinogenic-health risk assessment (NC-HRA)}

$\mathrm{HQ}$ and $\mathrm{HI}$ value in soils from all the selected land uses are below 1 , indicating no adverse health effects on adults and children. In rural, Industrial and commercial soils the $\mathrm{HI}$ value follows the order $\mathrm{Cr}>\mathrm{Co}>\mathrm{Cd}>\mathrm{Pb}>\mathrm{Ni}>\mathrm{Cu}>\mathrm{Zn}$, while Co replaces $\mathrm{Cr}$ in residential soils. Adimalla [3] have reported that $\mathrm{Cr}$ is the main reason for health risk in urban soils of India. Then the order in residential soils follows as $\mathrm{Co}>\mathrm{Cr}>\mathrm{Cd}>\mathrm{Pb}>\mathrm{Ni}>\mathrm{Cu}>\mathrm{Zn}$. For all the metals the general trend follows as $\mathrm{HQ}$ ing $>\mathrm{HQ}$ der $>\mathrm{HQ}$ inh with the exception of cobalt. For adults, $\mathrm{HQ}$ inh $>\mathrm{HQ}$ der for cobalt whereas for children, $\mathrm{HQ}$ der $>\mathrm{HQ}$ inh. For $\mathrm{Cd}, \mathrm{HI}$ value in industrial $\left(105.93 * 10^{-4}\right)$ and residential $\left(104.96 * 10^{-4}\right)$ is higher than rural and commercial for both adults and children. HI for Co (adult-528.60; child-4833.94) is highest in residential soils whereas for $\mathrm{Cr}$ (adult-533.00; child4626.22) highest is observed in commercial soils. Higher $\mathrm{HI}$ for $\mathrm{Zn}$ and $\mathrm{Pb}$ is observed in commercial and residential soils. Rural soils are observed to show higher $\mathrm{HI}$ value for $\mathrm{Ni}$. In general, the soils collected from different land use of 

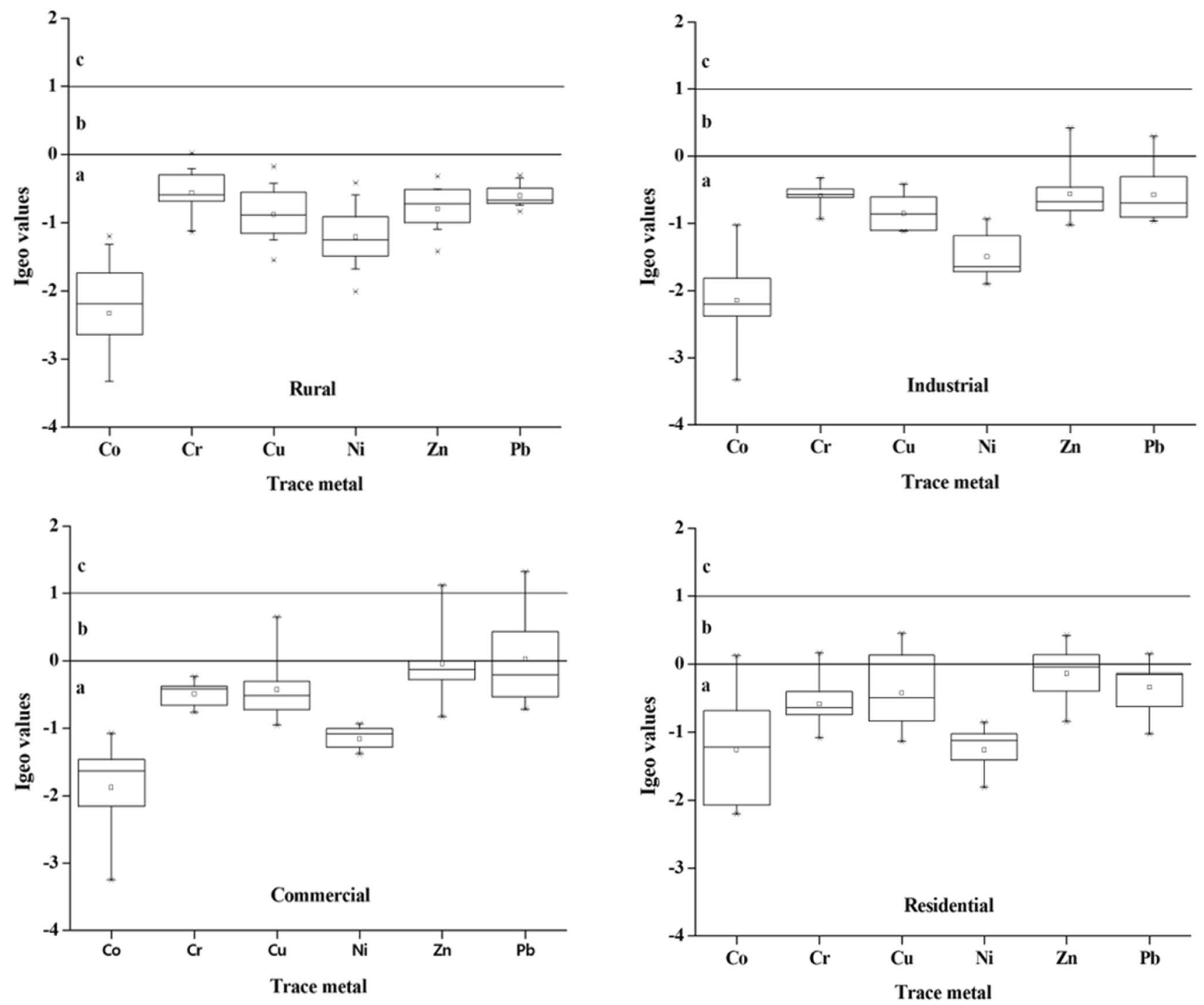

Fig. 3 Box and Whisker plots showing Geo-accumulation index (lgeo) of metals in soils collected from different land use of Gurugram

Gurugram showed no adverse health effects concerning non-cancer risk (Table 7).

\subsection{Correlation analysis}

As indicated in correlations (Table 8), Co correlates with Fe $(0.83)$ and $M n\left(r^{2}=0.78\right)$, suggesting its sources being geogenic. $\mathrm{Cr}$ correlates with $\mathrm{Fe}$ in industrial $\left(r^{2}=0.79\right)$, commercial $\left(r^{2}=0.67\right)$ and residential $\left(r^{2}=0.69\right)$ and $M n$ while no correlation with any other element. This suggests its source being parent rock. Cu show a strong correlation with $\mathrm{pH}\left(\mathrm{r}^{2}=0.88\right)$ similar to studies done by Krishna and Govil [30]. Cu show strong correlation with Fe $\left(r^{2}=0.87\right)$ and $\mathrm{Mn}\left(\mathrm{r}^{2}=0.87\right)$ in rural soils only and with $\mathrm{Cr}$ in industrial $\left(r^{2}=0.59\right)$ and residential $\left(r^{2}=0.83\right)$. It is also correlated with OM in industrial $\left(r^{2}=0.74\right)$, commercial $\left(r^{2}=0.87\right)$ and residential $\left(r^{2}=0.68\right)$ soils as found in studies of Adriano [4]. Variations in correlation in different land uses suggest its origin from mixed types of sources. $\mathrm{Ni}$ is found to be correlated with $\mathrm{Fe}, \mathrm{Cr}$ in rural $\left(\mathrm{r}^{2}=0.95,0.89\right)$, industrial $\left(r^{2}=0.89,0.52\right)$ and commercial $\left(r^{2}=0.83,0.69\right)$. association with these two metals suggest its presence from natural sources. It is also found to be correlated with $\mathrm{pH}\left(\mathrm{r}^{2}=0.65\right)$. $\mathrm{Pb}$ show correlation with $\mathrm{OM}$ in rural $\left(\mathrm{r}^{2}=0.69\right)$, industrial $\left(r^{2}=0.63\right)$ and commercial $\mathrm{Mn}\left(r^{2}=0.88\right)$ and with $\mathrm{Cu}$ in industrial $\left(r^{2}=0.89\right)$, commercial $\left(r^{2}=0.84\right)$ and residential $\left(r^{2}=0.69\right)$. This suggests its origin being anthropogenic. Similar to $\mathrm{Pb}, \mathrm{Zn}$ show correlation with $\mathrm{OM}, \mathrm{Cu}, \mathrm{Pb}$ in rural $\left(r^{2}=0.75,0.81,0.92\right)$, industrial $\left(r^{2}=0.75,0.81,0.92\right)$, and commercial $\left(r^{2}=0.90,0.98,0.87\right)$ respectively. $Z n$ is also found to be correlated with $\mathrm{Ni}, \mathrm{Cu}$, and $\mathrm{Rb}$ This indicates its source of origin to be mixed type, i.e. both anthropogenic 
Table 5 Average values of geoaccumulation index, enrichment factor, contamination factor and pollution load index for all sites

\begin{tabular}{|c|c|c|c|c|c|c|c|}
\hline Descriptive statistics & Co & $\mathrm{Cr}$ & $\mathrm{Cu}$ & $\mathrm{Ni}$ & $\mathrm{Pb}$ & $\mathrm{Zn}$ & \\
\hline \multicolumn{8}{|c|}{ Geoacumulation Index (Igeo) } \\
\hline Rural & -2.33 & -0.57 & -0.89 & -1.21 & -0.61 & -0.80 & \\
\hline Industrial & -2.14 & -0.59 & -0.86 & -1.50 & -0.58 & -0.56 & \\
\hline Commercial & -1.88 & -0.49 & -0.43 & -1.16 & 0.02 & -0.05 & \\
\hline Residential & -1.26 & -0.59 & -0.43 & -1.26 & -0.34 & -0.14 & \\
\hline \multicolumn{8}{|l|}{ Enrichment factor (EF) } \\
\hline Rural & 0.48 & 1.49 & 1.22 & 0.96 & 1.47 & 1.28 & \\
\hline Industrial & 0.53 & 1.44 & 1.20 & 0.77 & 1.50 & 1.52 & \\
\hline Commercial & 0.58 & 1.42 & 1.58 & 0.89 & 2.37 & 2.11 & \\
\hline Residential & 0.98 & 1.41 & 1.62 & 0.88 & 1.69 & 1.94 & \\
\hline \multicolumn{8}{|c|}{ Contamination factor (CF) } \\
\hline Rural & 0.35 & 1.04 & 0.84 & 0.68 & 0.99 & 0.88 & \\
\hline Industrial & 0.37 & 1.00 & 0.84 & 0.54 & 1.05 & 1.07 & \\
\hline Commercial & 0.44 & 1.08 & 1.17 & 0.67 & 1.75 & 1.56 & \\
\hline Residential & 0.72 & 1.02 & 1.19 & 0.64 & 1.22 & 1.42 & \\
\hline \multicolumn{8}{|c|}{ Pollution Load Index (PLI) } \\
\hline Rural & - & - & - & - & - & - & 0.74 \\
\hline Industrial & - & - & - & - & - & - & 0.74 \\
\hline Commercial & - & - & - & - & - & - & 0.88 \\
\hline Residential & - & - & - & - & - & - & 0.97 \\
\hline
\end{tabular}

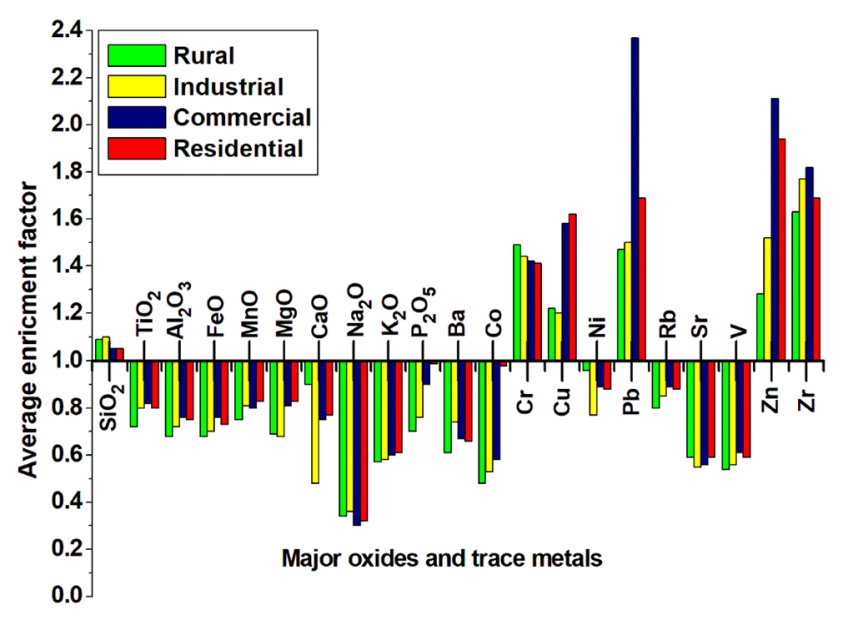

Fig. 4 Plot showing average EF for major oxides and trace metals

and geogenic. Other trace metals $(\mathrm{Ba}, \mathrm{Sr}, \mathrm{Rb}, \mathrm{Zr}, \mathrm{V})$ show correlation with $\mathrm{Fe}$ and $\mathrm{Mn}$ this suggests their origin being dominantly geogenic.

\subsection{Principal component analysis (PCA)}

Five principal components are considered during the PCA (Table 9), accounting for $81.66 \%$ of the total variance. $\mathrm{PC} 1$ is dominated by $\mathrm{TiO}_{2}, \mathrm{Al}_{2} \mathrm{O}_{3}, \mathrm{MgO}, \mathrm{MnO}, \mathrm{FeO}, \mathrm{K}_{2} \mathrm{O}, \mathrm{Rb}$ and $\mathrm{V}$, accounting for $31.01 \%$ of the total variance. These elements, which are generally associated with natural geochemical rock-forming processes reflect their parental origin. $\mathrm{PC} 2$ is dominated by $\mathrm{CaO}, \mathrm{Cr}, \mathrm{Ni}$ and $\mathrm{Sr}$ and accounts for $19.96 \%$ of the variance. Sources of these elements being natural. $\mathrm{CaO}$ is naturally found as carbonates in soils [38] and Sr is naturally associated with Kankar and limestone [30] which is dominantly found in soils of Gurugram [38]. PC3 is dominated by $\mathrm{Cu}, \mathrm{Pb}$, and $\mathrm{Zn}$ accounting for $15.71 \%$ of the total variance with $\mathrm{P}_{2} \mathrm{O}_{5}$. The strong relationship among these three elements indicates their source to be dominantly anthropogenic, mainly from vehicular emissions and automobile manufacturing units which are widely distributed in Gurugram. $\mathrm{Zn}$ is used as an additive in the vulcanization process of tyres and hence wear and tear of tyres is the main source of Zn. Cu-brass automotive radiator and motor parts use $\mathrm{Cu}$ due to its properties like high corrosive resistance and high thermal conductivity. Zr is univocally present in PC4 and shows weak association with all other components. This indicates although its origin is geogenic (as suggested in correlation), but it has come from windblown dust. In $\mathrm{PC} 5, \mathrm{Na}_{2} \mathrm{O}$ and $\mathrm{Co}$ form a group indicating natural occurrence to be the dominant source as both are strongly correlated with $\mathrm{FeO}$ and $\mathrm{MnO}$.

\subsection{Spatial distribution of heavy metals}

The spatial distribution of $\mathrm{Co}, \mathrm{Ni}$, and $\mathrm{Cr}$ are distinctly different from the distribution pattern of $\mathrm{Cu}, \mathrm{Pb}$, and $\mathrm{Zn}$. High concentrations of $\mathrm{Cr}$ and $\mathrm{Ni}$ (Fig. 5b, d) are observed in the eastern part of Gurugram, while high concentrations of 
Table 6 Values of variables used for health risk assessment and their detailed description

\begin{tabular}{|c|c|c|c|c|c|}
\hline S. no. & Variable & Symbol & Unit & Value & References \\
\hline 1 & Concentration of metals in soil & $\mathrm{C}$ & $\mathrm{mg} / \mathrm{kg}$ & From this study & This study \\
\hline 2 & Soil ingestion rate & IR & mg/day & 200 (child), 100 (adult) & Luo et al. [36], USEPA [65] \\
\hline 3 & Exposure frequency & $\mathrm{EF}$ & day/year & 350 & Luo et al. [36], USEPA [66] \\
\hline 4 & Exposure duration & ED & year & 6 (child), 24 (Adult) & USEPA [64] \\
\hline 5 & Average body weight & BW & $\mathrm{kg}$ & 15 (child), 70 (adults) & Karim and Qureshi [28], USEPA [67] \\
\hline 6 & $\begin{array}{l}\text { Averaging time for non-carcino- } \\
\text { genic effects }\end{array}$ & Atnc & day & EDchild $\times 365$; EDadult $\times 365$ & Luo et al. [36], USDOE [63] \\
\hline 7 & Exposure time & ET & $h / d$ & 24 & USDOE [63] \\
\hline 8 & $\begin{array}{l}\text { Soil-to-air particulate emission } \\
\text { factor }\end{array}$ & PEF & $\mathrm{m}^{3} / \mathrm{kg}$ & $1.36 \times 10^{9}$ & USEPA [65] \\
\hline 9 & $\begin{array}{l}\text { Skin surface area available for } \\
\text { exposure }\end{array}$ & SA & $\mathrm{cm}^{2} /$ event & 2800 (child); 5700 (adult) & Luo et al. [36], USDOE [63] \\
\hline 10 & Soil to skin adherence factor & $\mathrm{AF}$ & $\mathrm{mg} / \mathrm{cm}^{2}$ & 0.2 (child); 0.07 (adult) & Equation (9) \\
\hline 11 & Dermal absorption factor & ABSd & unitless & 0.001 & Luo et al. [36], USEPA [65] \\
\hline 12 & Gastrointestinal absorption factor & ABSgi & Unitless & $\begin{array}{r}\mathrm{Co}, \mathrm{Cu}, \mathrm{Mn}, \mathrm{Pb} \text { and } \mathrm{Zn}(1), \mathrm{Cd} \\
(0.025), \mathrm{Cr}(0.013), \mathrm{Ni}(0.04)\end{array}$ & \\
\hline 13 & Chronic oral reference dose & $R_{f} D_{-}$ing & $\mathrm{mg} / \mathrm{kg} / \mathrm{day}$ & $\begin{array}{l}\mathrm{Cd}(0.001), \mathrm{Co}(0.0003), \mathrm{Cr}(0.003) \\
\mathrm{Cu}(0.04), \mathrm{Mn}(0.14), \mathrm{Ni}(0.02), \mathrm{Pb} \\
(0.0035), \mathrm{Zn}(0.3)\end{array}$ & $\begin{array}{l}\text { Adimalla and Wang [2], Luo } \\
\text { et al. [36], USEPA [64, 65] }\end{array}$ \\
\hline 14 & $\begin{array}{l}\text { Chronic inhalation reference con- } \\
\text { centration }\end{array}$ & $\mathrm{R}_{\mathrm{f}} \mathrm{C}_{-}$inh & $\mathrm{mg} / \mathrm{m}^{3}$ & $\begin{array}{l}\mathrm{Cd}(0.00001), \mathrm{Co}(0.000006), \mathrm{Mn} \\
\quad(0.00005), \mathrm{Ni}(0.00009)\end{array}$ & $\begin{array}{l}\text { Adimalla and Wang [2], Luo } \\
\text { et al. [36], USEPA [64, 65] }\end{array}$ \\
\hline 15 & Chronic dermal reference dose & $\mathrm{R}_{\mathrm{f}} \mathrm{D} \_\mathrm{der} \mathrm{a}^{\mathrm{a}}$ & $\mathrm{mg} / \mathrm{kg} / \mathrm{day}$ & $\begin{array}{l}\mathrm{Cd}(0.000025), \mathrm{Co}(0.0003), \mathrm{Cr} \\
(0.000039), \mathrm{Cu}(0.04), \mathrm{Mn}(0.14) \\
\mathrm{Ni}(0.0008), \mathrm{Pb}(0.0035), \mathrm{Zn}(0.3)\end{array}$ & $\begin{array}{l}\text { Adimalla and Wang [2], Luo } \\
\text { et al. [36], USEPA [64, 65] }\end{array}$ \\
\hline
\end{tabular}

${ }^{\mathrm{a}} \mathrm{RfD} \_$der (=RfD_ing*ABSgi)

Co (Fig. 5a) is observed only in a very narrow region of the northern part of the city. Higher concentrations of $\mathrm{Cu}, \mathrm{Pb}$, and $\mathrm{Zn}$ (Fig. 5 c, e, f) are found in the Sadar area (a dense commercial establishment) and also in some residential areas situated in the core of the city. The geochemical maps (Fig. 5) show a similar spatial distribution for $\mathrm{Cu}, \mathrm{Pb}$, and $\mathrm{Zn}$, which is consistent with the correlation described in the statistical results of this study. Gurugram is severely affected by unplanned solid waste management [7]; hence, improper commercial and residential waste dumping can be a common source governing the distribution of these metals.

\section{Conclusions}

Based on the results of investigations, the soils of Gurugram are sandy (75-85 wt\%) with average $\mathrm{pH}$ of 7.6, 7.3, 7.4 , and 7.3 in rural, industrial, commercial and residential soils, respectively, indicating its alkaline nature. The observed high OM content in residential soils (3.24 wt\%) and the commercial soils ( $2.51 \mathrm{wt} \%$ ) as compared to rural may be attributed to aerial organic pollutants (coal particles, soot, and other products of incomplete combustion of solid and liquid fuel). Common alumino-silicate minerals such as quartz, K-feldspar, muscovite and sodic plagioclase are abundant in the samples. The average concentration of all the metals is below permissible limits [70] except $Z n$ which shows values above the limits in all the land uses. Zn shows concentration 1.5 times higher in Industrial sites and almost twice in commercial and residential sites. High concentrations of $\mathrm{Zn}$ as compared to permissible limits indicate its sources to be anthropogenic and can be related to wear-and-tear of vehicle components and brake pads in heavy traffic zones. The average concentration of $\mathrm{Co}$ and $\mathrm{Cu}$ in residential soils, $\mathrm{Cr}$ in all the land uses, and $\mathrm{Zn}$ in commercial and residential soils is above world average soil value given by Adriano [4]. At the rural and industrial sites, the distribution of metals follows the order $\mathrm{Co}<\mathrm{Pb}<\mathrm{Cu}<\mathrm{Ni}<\mathrm{Zn}<\mathrm{Cr}$. At commercial and residential sites, $\mathrm{Zn}$ gets enriched, and the order follows as $\mathrm{Co}<\mathrm{Cu}=\mathrm{Ni}=\mathrm{Pb}<\mathrm{Cr}<\mathrm{Zn}$.

Based on the calculated average Igeo values of selected samples, soils of Gurugram, in general, are uncontaminated and have value $<1$. However, few samples are found to be moderately contaminated. Average CF values suggest soils of Gurugram show moderate contamination for: $\mathrm{Cr}$ in all the four land uses; $\mathrm{Cu}$ in commercial and residential soils; $\mathrm{Pb}$ and $\mathrm{Zn}$ in industrial, commercial, and residential soils. Low contamination is observed for $\mathrm{Cr}$ in 


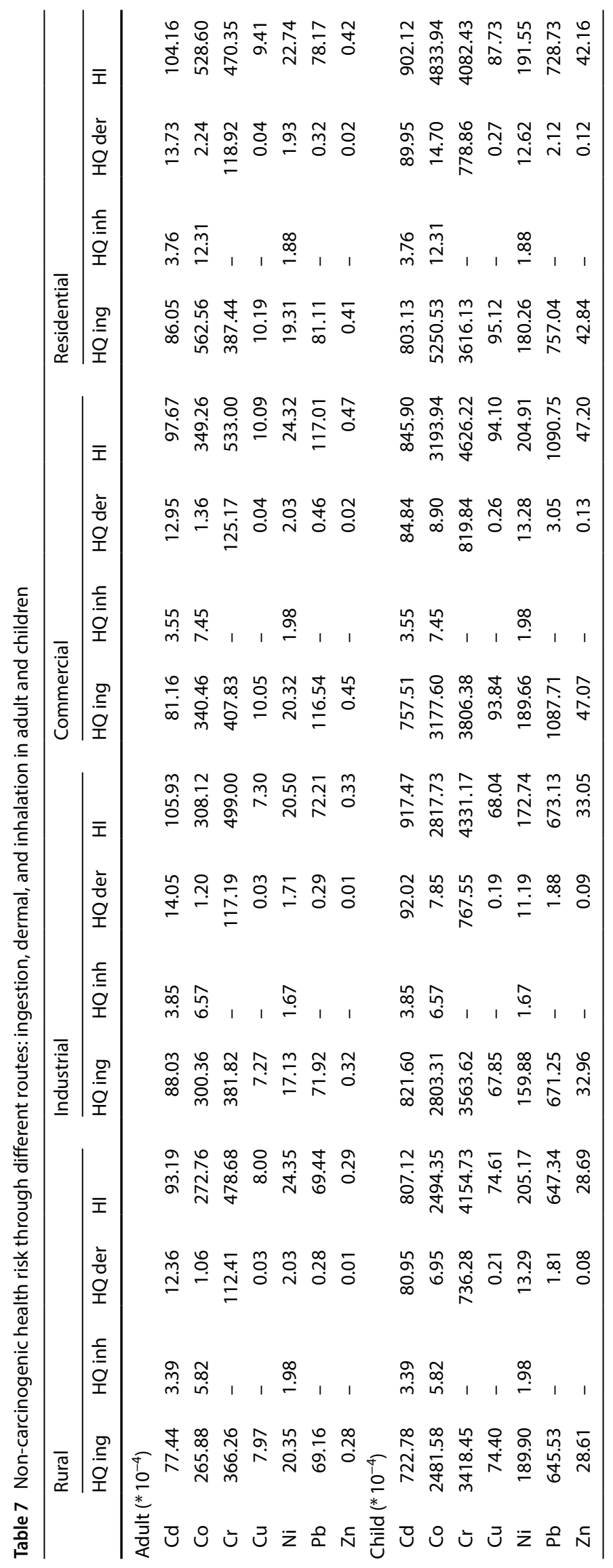


Table 8 Correlation matrix for trace metals in soils collected from different landuse areas from Gurugram city (values in bold show significant values i.e. $>0.5$ )

\begin{tabular}{|c|c|c|c|c|c|c|c|c|c|c|c|c|c|c|c|c|}
\hline & Site & $\mathrm{pH}$ & $\mathrm{OM}$ & $\mathrm{Fe}$ & $\mathrm{Mn}$ & $\mathrm{Ba}$ & Co & $\mathrm{Cr}$ & $\mathrm{Cu}$ & $\mathrm{Ni}$ & $\mathrm{Pb}$ & $\mathrm{Rb}$ & $\mathrm{Sr}$ & V & $\mathrm{Zn}$ & $\mathrm{Zr}$ \\
\hline \multirow[t]{4}{*}{$\mathrm{pH}$} & Rural & & & & & & & & & & & & & & & \\
\hline & Industrial & & & & & & & & & & & & & & & \\
\hline & Commercial & & & & & & & & & & & & & & & \\
\hline & Residential & & & & & & & & & & & & & & & \\
\hline \multirow[t]{4}{*}{$\mathrm{OM}$} & Rural & ns & & & & & & & & & & & & & & \\
\hline & Industrial & ns & & & & & & & & & & & & & & \\
\hline & Commercial & ns & & & & & & & & & & & & & & \\
\hline & Residential & ns & & & & & & & & & & & & & & \\
\hline \multirow[t]{4}{*}{$\mathrm{Fe}$} & Rural & 0.60 & ns & & & & & & & & & & & & & \\
\hline & Industrial & ns & ns & & & & & & & & & & & & & \\
\hline & Commercial & ns & ns & & & & & & & & & & & & & \\
\hline & Residential & ns & ns & & & & & & & & & & & & & \\
\hline \multirow[t]{4}{*}{$\mathrm{Mn}$} & Rural & $0.80 *$ & ns & $0.79 *$ & & & & & & & & & & & & \\
\hline & Industrial & ns & ns & $0.78 *$ & & & & & & & & & & & & \\
\hline & Commercial & ns & ns & 0.53 & & & & & & & & & & & & \\
\hline & Residential & ns & ns & $0.82 * *$ & & & & & & & & & & & & \\
\hline \multirow[t]{4}{*}{$\mathrm{Ba}$} & Rural & ns & ns & ns & ns & & & & & & & & & & & \\
\hline & Industrial & ns & ns & -0.54 & ns & & & & & & & & & & & \\
\hline & Commercial & ns & $0.81 * *$ & ns & ns & & & & & & & & & & & \\
\hline & Residential & ns & ns & $0.65^{*}$ & $0.67 *$ & & & & & & & & & & & \\
\hline \multirow[t]{4}{*}{ Co } & Rural & ns & ns & $0.83^{*}$ & $0.78 *$ & ns & & & & & & & & & & \\
\hline & Industrial & ns & ns & ns & ns & ns & & & & & & & & & & \\
\hline & Commercial & ns & ns & ns & ns & ns & & & & & & & & & & \\
\hline & Residential & ns & ns & ns & ns & ns & & & & & & & & & & \\
\hline \multirow[t]{4}{*}{$\mathrm{Cr}$} & Rural & ns & ns & $0.79 *$ & $0.87 *$ & ns & $0.87^{*}$ & & & & & & & & & \\
\hline & Industrial & ns & 0.55 & $0.67^{*}$ & 0.65 & ns & ns & & & & & & & & & \\
\hline & Commercial & ns & ns & $0.69 *$ & ns & ns & ns & & & & & & & & & \\
\hline & Residential & ns & ns & ns & ns & ns & $0.72 *$ & & & & & & & & & \\
\hline \multirow[t]{4}{*}{$\mathrm{Cu}$} & Rural & $0.88^{* *}$ & ns & 0.74 & $0.89 * *$ & ns & ns & ns & & & & & & & & \\
\hline & Industrial & ns & $0.74^{*}$ & ns & ns & ns & ns & 0.59 & & & & & & & & \\
\hline & Commercial & ns & $0.87^{* *}$ & ns & ns & 0.56 & ns & ns & & & & & & & & \\
\hline & Residential & ns & $0.68^{*}$ & ns & ns & ns & ns & $0.83^{* *}$ & & & & & & & & \\
\hline \multirow[t]{4}{*}{$\mathrm{Ni}$} & Rural & 0.65 & ns & $0.95 * *$ & $0.81 * *$ & ns & $0.86 *$ & $0.89 * *$ & $0.82 *$ & & & & & & & \\
\hline & Industrial & ns & ns & $0.89 * *$ & ns & ns & ns & 0.52 & 0.61 & & & & & & & \\
\hline & Commercial & ns & ns & $0.83 * *$ & ns & ns & ns & $0.69 *$ & ns & & & & & & & \\
\hline & Residential & ns & $0.66 *$ & $0.66^{*}$ & ns & ns & ns & ns & ns & & & & & & & \\
\hline \multirow[t]{4}{*}{$\mathrm{Pb}$} & Rural & ns & 0.69 & ns & ns & ns & ns & ns & ns & ns & & & & & & \\
\hline & Industrial & ns & 0.63 & ns & ns & ns & ns & 0.53 & $0.89 * *$ & ns & & & & & & \\
\hline & Commercial & ns & $0.88^{* *}$ & ns & ns & ns & ns & ns & $0.84 * *$ & ns & & & & & & \\
\hline & Residential & ns & ns & ns & ns & ns & ns & ns & $0.69 *$ & ns & & & & & & \\
\hline \multirow[t]{4}{*}{$\mathrm{Rb}$} & Rural & ns & ns & 0.71 & 0.26 & 0.67 & 0.69 & ns & ns & ns & ns & & & & & \\
\hline & Industrial & ns & $0.75^{*}$ & $0.84 * *$ & ns & ns & ns & 0.61 & 0.56 & $0.82 * *$ & ns & & & & & \\
\hline & Commercial & ns & -0.30 & ns & ns & ns & ns & ns & ns & ns & ns & & & & & \\
\hline & Residential & ns & ns & $0.76 * *$ & $0.65^{*}$ & $0.63 *$ & ns & ns & ns & ns & ns & & & & & \\
\hline \multirow[t]{4}{*}{$\mathrm{Sr}$} & Rural & ns & ns & ns & ns & ns & ns & ns & ns & ns & ns & ns & & & & \\
\hline & Industrial & ns & ns & ns & ns & 0.60 & ns & ns & ns & ns & ns & ns & & & & \\
\hline & Commercial & ns & $0.68^{*}$ & ns & ns & ns & ns & ns & $0.73 *$ & ns & $0.84 * *$ & ns & & & & \\
\hline & Residential & ns & ns & ns & ns & ns & ns & ns & ns & ns & ns & ns & & & & \\
\hline V & Rural & ns & ns & 0.58 & $0.89 * *$ & ns & ns & 0.52 & ns & ns & ns & ns & ns & & & \\
\hline
\end{tabular}


Table 8 (continued)

\begin{tabular}{|c|c|c|c|c|c|c|c|c|c|c|c|c|c|c|c|c|}
\hline & Site & $\mathrm{pH}$ & OM & $\mathrm{Fe}$ & $\mathrm{Mn}$ & $\mathrm{Ba}$ & Co & $\mathrm{Cr}$ & $\mathrm{Cu}$ & $\mathrm{Ni}$ & $\mathrm{Pb}$ & $\mathrm{Rb}$ & $\mathrm{Sr}$ & V & $\mathrm{Zn}$ & $\mathrm{Zr}$ \\
\hline & Industrial & ns & ns & 0.58 & $0.89 * *$ & ns & ns & 0.52 & ns & ns & ns & ns & ns & & & \\
\hline & Commercial & ns & ns & $0.78 * *$ & ns & ns & ns & ns & ns & 0.61 & ns & ns & ns & & & \\
\hline & Residential & ns & ns & $0.78 * *$ & ns & $0.71 *$ & ns & ns & ns & $0.64 *$ & ns & $0.83 * *$ & ns & & & \\
\hline \multirow[t]{4}{*}{$\mathrm{Zn}$} & Rural & ns & $0.75^{*}$ & ns & ns & 0.15 & ns & ns & $0.81 * *$ & 0.52 & $0.92 * *$ & $0.69 *$ & ns & ns & & \\
\hline & Industrial & ns & $0.75^{*}$ & ns & ns & ns & ns & ns & $0.81 * *$ & 0.52 & $0.92 * *$ & $0.69 *$ & ns & ns & & \\
\hline & Commercial & ns & $0.90 * *$ & ns & ns & $0.63 *$ & ns & ns & $0.98 * *$ & ns & ns & ns & $0.75^{*}$ & ns & & \\
\hline & Residential & ns & ns & ns & ns & ns & ns & 0.54 & 0.56 & 0.59 & ns & ns & ns & ns & & \\
\hline \multirow[t]{4}{*}{$\mathrm{Zr}$} & Rural & ns & ns & ns & $0.76^{*}$ & ns & ns & 0.66 & 0.61 & ns & ns & ns & ns & 0.64 & ns & \\
\hline & Industrial & ns & ns & ns & ns & ns & ns & ns & ns & ns & ns & ns & ns & ns & ns & \\
\hline & Commercial & ns & ns & ns & ns & ns & ns & ns & ns & ns & ns & ns & ns & ns & ns & \\
\hline & Residential & ns & ns & ns & ns & ns & ns & ns & ns & ns & ns & ns & ns & ns & ns & \\
\hline
\end{tabular}

**Correlation is significant at the 0.01 level (2-tailed). ${ }^{*}$ Correlation is significant at the 0.05 level (2-tailed)

ns not significant (all values $<0.5$ )

Table 9 The matrix of Principal component analysis loadings major elements and trace elements in Gurugram soils (values in bold show significant values i.e. $>0.5$ )

\begin{tabular}{lrrrrr}
\hline & \multicolumn{1}{c}{$\mathrm{PC1}$} & \multicolumn{1}{c}{$\mathrm{PC2}$} & \multicolumn{1}{c}{$\mathrm{PC} 3$} & \multicolumn{1}{c}{$\mathrm{PC4}$} & \multicolumn{1}{c}{$\mathrm{PC5}$} \\
\hline $\mathrm{SiO}_{2}$ & -0.56 & -0.66 & -0.11 & -0.03 & 0.11 \\
$\mathrm{TiO}_{2}$ & $\mathbf{0 . 8 8}$ & 0.07 & 0.05 & 0.41 & 0.07 \\
$\mathrm{Al}_{2} \mathrm{O}_{3}$ & $\mathbf{0 . 9 4}$ & 0.03 & -0.08 & -0.10 & -0.05 \\
$\mathrm{MgO}$ & $\mathbf{0 . 7 0}$ & 0.58 & 0.22 & 0.00 & 0.05 \\
$\mathrm{FeO}$ & $\mathbf{0 . 9 1}$ & 0.39 & 0.06 & 0.03 & -0.07 \\
$\mathrm{MnO}$ & $\mathbf{0 . 6 7}$ & 0.19 & 0.17 & 0.37 & 0.21 \\
$\mathrm{CaO}$ & 0.00 & $\mathbf{0 . 9 6}$ & 0.03 & 0.14 & -0.05 \\
$\mathrm{Na}{ }_{2} \mathrm{O}$ & -0.25 & -0.28 & -0.34 & 0.04 & $\mathbf{0 . 7 1}$ \\
$\mathrm{K} \mathrm{O}_{2}$ & $\mathbf{0 . 9 3}$ & 0.10 & 0.04 & -0.14 & 0.08 \\
$\mathrm{P}_{2} \mathrm{O}_{5}$ & -0.01 & -0.04 & $\mathbf{0 . 9 0}$ & 0.11 & 0.09 \\
$\mathrm{Ba}$ & 0.02 & -0.21 & 0.09 & -0.56 & 0.16 \\
$\mathrm{Cd}$ & -0.28 & -0.65 & 0.13 & -0.39 & 0.36 \\
$\mathrm{Co}$ & 0.33 & 0.32 & 0.17 & -0.04 & $\mathbf{0 . 6 7}$ \\
$\mathrm{Cr}$ & 0.31 & $\mathbf{0 . 7 1}$ & 0.05 & 0.04 & 0.22 \\
$\mathrm{Cu}$ & 0.11 & 0.42 & $\mathbf{0 . 8 2}$ & -0.09 & -0.02 \\
$\mathrm{Ni}$ & 0.60 & $\mathbf{0 . 6 6}$ & 0.12 & 0.00 & -0.14 \\
$\mathrm{~Pb}$ & -0.02 & -0.01 & $\mathbf{0 . 8 7}$ & -0.09 & -0.28 \\
$\mathrm{Rb}$ & $\mathbf{0 . 9 2}$ & -0.19 & 0.08 & -0.20 & -0.07 \\
$\mathrm{Sr}$ & -0.37 & $\mathbf{0 . 7 0}$ & 0.30 & -0.17 & 0.14 \\
$\mathrm{~V}$ & $\mathbf{0 . 7 3}$ & 0.42 & 0.06 & 0.40 & -0.01 \\
$\mathrm{Zn}$ & 0.19 & 0.06 & $\mathbf{0 . 9 2}$ & -0.10 & 0.09 \\
$\mathrm{Zr}$ & 0.00 & -0.15 & -0.02 & $\mathbf{0 . 9 1}$ & 0.17 \\
Eigen value & $\mathbf{6 . 8 2}$ & $\mathbf{4 . 3 9}$ & $\mathbf{3 . 4 6}$ & $\mathbf{1 . 9 1}$ & $\mathbf{1 . 3 9}$ \\
$\mathrm{Variance}(\%)$ & $\mathbf{3 1 . 0 1}$ & $\mathbf{1 9 . 9 6}$ & $\mathbf{1 5 . 7 1}$ & $\mathbf{8 . 6 7}$ & $\mathbf{6 . 3 1}$ \\
\hline & & & & &
\end{tabular}

rural soils, and $\mathrm{Co}$ and $\mathrm{Ni}$ in all the land uses. In general, soils show moderate contamination based on the average $\mathrm{CF}$ values. $\mathrm{PLI}$, which gives cumulative pollution of all the metals for a site suggest perfection which means no contamination. The average EF values for various toxic trace metals soils of Gurugram show minor enrichment for $\mathrm{Cr}, \mathrm{Cu}, \mathrm{Pb}$ and $\mathrm{Zn}$ while no enrichment for $\mathrm{Co}$ and $\mathrm{Ni}$ in all the land uses. In health risk assessment, $\mathrm{HQ}$ and $\mathrm{HI}$ value in soils from all the selected land uses are $<1$ indicating no adverse health effects on adults and children. For all the metals the general trend follows as $\mathrm{HQ}$ ing $>\mathrm{HQ}$ der $>\mathrm{HQ}$ inh. $\mathrm{TiO}_{2}, \mathrm{Al}_{2} \mathrm{O}_{3}, \mathrm{MgO}, \mathrm{MnO}, \mathrm{FeO}, \mathrm{K}_{2} \mathrm{O}, \mathrm{Rb}, \mathrm{Co}$ and $V$ together in one group suggest their sources being common and that is parental rock. $\mathrm{Cr}$ and Ni form group with $\mathrm{CaO}$ and $\mathrm{Sr}$ suggesting their similar source of origin and i.e. parental rock. $\mathrm{Cu}, \mathrm{Pb}$ and $\mathrm{Zn}$ form a separate group with $\mathrm{P}_{2} \mathrm{O}_{5}$ suggesting anthropogenic as their dominant sources, with $\mathrm{Pb}$ mainly from vehicular emissions and automobile manufacturing units, $\mathrm{Zn}$ from wear and tear of tyres and $\mathrm{Cu}$ from brass automotive radiator and motor parts. All these are widely distributed in Gurugram. Zr is univocally present in a different group suggesting a different source which is geogenic (as suggested in correlation) but has come from windblown Thar dust. The association of $\mathrm{Co}$ with $\mathrm{FeO}$ and $\mathrm{MnO}$ in a different group suggests its natural origin. In general, correlation and PCA suggests, $\mathrm{Co}, \mathrm{Cr}$ and $\mathrm{Ni}$ being geologically controlled whereas $\mathrm{Cu}, \mathrm{Pb}$ and $\mathrm{Zn}$ is mixed type (geologic as well as anthropologic). The geochemical maps (Fig. 5) show a similar spatial distribution for $\mathrm{Cu}, \mathrm{Pb}$, and $\mathrm{Zn}$, which is consistent with the correlation and they are found to be dominated in some commercial and residential sites.

Based on the results, it is concluded that the soils of Gurugram are alkaline and unpolluted. The main metal of concern is $\mathrm{Zn}$ followed by $\mathrm{Cu}$ and $\mathrm{Pb}$. Although, in general, soils are uncontaminated based on an average concentration, however, certain hotspots are observed for $\mathrm{Cu}, \mathrm{Pb}$ and $\mathrm{Zn}$, which show moderate pollution and warrants early management. Furthermore, the satellite cities 

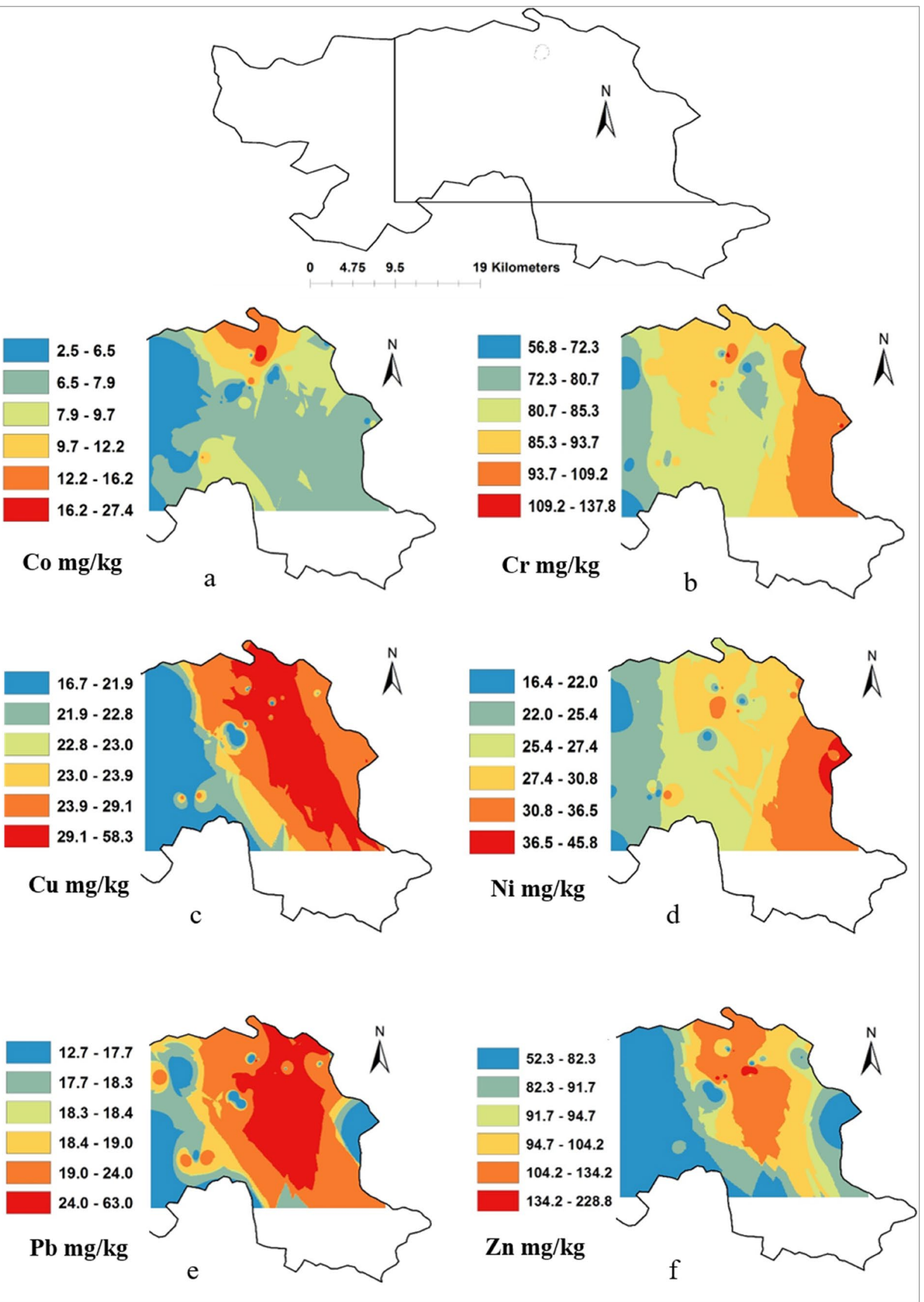

Fig. 5 Spatial distribution maps of potentially toxic trace metals in soils of Gurugram block 
like Gurugram, with the fast pace of development, need further detailed studies to understand the effect of rapid urbanization on the environment.

Acknowledgements We thank the Dean, School of Environmental Sciences, JNU for encouragement and the Department of Science and Technology (Purse-Phase-II) for financial support. AD acknowledge the Council of Scientific and Industrial Research, New Delhi for Junior Research Fellowship. The authors thank Mr. Chibuike Chigbo (Research Associate, Centre of Boreal Research - NAIT, Peace River, Alberta, Canada) for improving the language of this manuscript.

Funding This work was part of an M.Phil. dissertation which was funded by the Council of Scientific and Industrial Research (CSIR), New Delhi (Grant No. 09/263(1055)/2015-EMR-1).

\section{Compliance with ethical standards}

Conflict of interest On behalf of all authors, the corresponding author states that there is no conflict of interest.

\section{References}

1. Achary MS, Panigrahi S, Satpathy KK, Prabhu R, Panigrahy RC (2016) Health risk assessment and seasonal distribution of dissolved trace metals in surface waters of Kalpakkam, southwest coast of Bay of Bengal. Reg Stud Mar Sci 6:96-108

2. Adimalla N, Wang $\mathrm{H}$ (2018) Distribution, contamination, and health risk assessment of heavy metals in surface soils from northern Telangana. India. Arab J Geosciences 11(21):684

3. Adimalla N, Qian H, Wang H (2019) Assessment of heavy metal (HM) contamination in agricultural soil lands in northern Telangana, India: an approach of spatial distribution and multivariate statistical analysis. Environ Monit Assess 191(4):246

4. Adriano DC (2001) Biogeochemical processes regulating metal behaviour. In: Adriano DC (ed) Trace elements in terrestrial environments, 2nd edn. Springer, New York, pp 30-57

5. Alloway BJ (1995) Soil processes and the behavior of metals. In: Alloway BJ (ed) Heavy metals in soils. Blackie Academic \& Professional, London, pp 38-57

6. Awashthi SK (2000) Prevention of Food Adulteration Act No. 37 of 1954. In: Central and State rules as amended for 1999, 3rd edn. Ashoka Law House, New Delhi

7. Bandyopadhyay S (2013) Solid waste management, an environmental challenge in Millennium Cyber City in India, Gurgaon. In: Proceedings REAL CORP Tagungsband, pp 811-819

8. Brady NC (2013) The nature and properties of soil. Eurasia Publishing House, New Delhi

9. Bretzel F, Calderisi M (2006) Metal contamination in urban soils of coastal Tuscany (Italy). Environ Monit Assess 118(1-3):319-335

10. Cempel M, Nikel GJPJS (2006) Nickel: a review of its sources and environmental toxicology. Polish J Environ stud 15(3):375-382

11. CGWB (1995) Ground Water Resources of India, Gurgaon district at a glance. Central Ground Water Board, New Delhi. http:// cgwb.gov.in/District_Profile/Haryana/Gurgaon.pdf

12. Chabukdhara M, Nema AK (2013) Heavy metals assessment in urban soil around industrial clusters in Ghaziabad, India: probabilistic health risk approach. Ecotoxicol Environ Saf 87:57-64

13. Chakrapany RA (1981) Hydrology of Gurgaon District, Haryana. Central Ground Water Board, Ministry of Irrigation, Govt. of India

14. Chaudhary BS, Kumar M, Roy AK, Ruhal DS (1996) Applications of remote sensing and GIS in groundwater investigations in
Sohna block, Gurgaon district, Haryana, India. Int Arch Photogramm Remote Sens 31:18-23

15. Chen CW, Kao CM, Chen CF, Dong CD (2007) Distribution and accumulation of metals in sediments of Kaoshiung Harbor, Taiwan. Chemosphere 66:1431-1440

16. Cui L, Shi J (2012) Urbanization and its environmental effects in Shanghai, China. Urban Clim 2:1-15

17. Czarnowska K (1980) Heavy metal accumulation in soils, plants and some animals from Warsaw area. Rocz Glebozn 31(1):77-113

18. Dawson RJ, Hall JW, Barr S, Batty M, Bristow A, Carney S, Dagoumas A, Evans S, Ford A, Harwatt H, Köhler J (2009) A blueprint for the integrated assessment of climate change in cities. Tyndall Centre for Climate Change Research, Working Paper 129

19. De Miguel E, Iribarren I, Chacon E, Ordonez A, Charlesworth $S$ (2007) Risk-based evaluation of the exposure of children to trace elements in playgrounds in Madrid (Spain). Chemosphere 66(3):505-513

20. Ergin M, Saydam C, Basturk O, Erdem E, Yoruk R (1991) Metal concentrations in surface sediments from the two coastal inlets (Golden Horn Estuary and Izmit Bay) of the northeastern Sea of Marmara. Chem Geol 91:269-285

21. Galitskova YM, Murzayeva Al (2016) Urban soil contamination. Procedia Eng 153:162-166

22. Govil P, Reddy G, Krishna A (2001) Contamination of soil due to heavy metals in the Patancheru industrial development area, Andhra Pradesh, India. Environ Geol 41(3-4):461-469

23. Hakanson $L$ (1980) An ecological risk index for aquatic pollution control, a sedimentological approach. Water Res 14:975-1001

24. Heilig GK (2012) World urbanization prospects: the 2011 revision. United Nations, Department of Economic and Social Affairs (DESA), Population Division, Population Estimates and Projections Section New York 14

25. Ivanov VV (1994) Environmental geochemistry of the elements. Nedra Ekologiya, Moscow

26. Jadhao RB (2013) Assessment of quality of soil for the improvement of agriculture activities in Najafgarh Area, Gurgaon, Haryana. Int J Innov Res Dev 2(2):665-683

27. Kabata-Pendias A, Mukherjee AB (2007) Trace elements from soil to human. Springer, Berlin

28. Karim Z, Qureshi BA (2014) Health risk assessment of heavy metals in urban soil of Karachi, Pakistan. Hum Ecol Risk Assess Int J 20(3):658-667

29. Khan S, Cao Q, Zheng YM, Huang YZ, Zhu YG (2008) Health risks of heavy metals in contaminated soils and food crops irrigated with wastewater in Beijing, China. Environ Pollut 152(3):686-692

30. Krishna AK, Govil PK (2007) Soil contamination due to heavy metals from an industrial area of Surat, Gujarat, Western India. Environ Monit Assess 124(1-3):263-275

31. Kumar A, Hooda RS, Goyal A, Goel A (2015) Satellite data based groundwater prospects study in Gurgaon District, Haryana, India. Res J Recent Sci 4:255-260

32. Kumar A, Ramanathan AL, Prasad MBK, Datta D, Kumar M, Sappal SM (2014) Distribution, enrichment, and potential toxicity of trace metals in the surface sediments of Sundarban mangrove ecosystem, Bangladesh: a baseline study before Sundarban oil spill of December, 2014. Environ Sci Pollut Res 23(9):8985-8999

33. Li X, Poon CS, Liu PS (2001) Heavy metal contamination of urban soils and street dusts in Hong Kong. Appl Geochem 16(11):1361-1368

34. Li X, Lee SL, Wong SC, Shi W, Thornton I (2004) The study of metal contamination in urban soils of Hong Kong using a GIS-based approach. Environ Poll 129(1):113-124

35. Lohani M (2014) Impact of landuse change on hydrology: a case study of Gurgaon City. Int J Environ Res Dev 4(3):247-252 
36. Luo XS, Ding J, Xu B, Wang YJ, Li HB, Yu S (2012) Incorporating bioaccessibility into human health risk assessments of heavy metals in urban park soils. Sci Total Environ 424:88-96

37. Mahmood G, Ishrat G, Kumar R, Agarwal M (2012) Prediction for improvement in agriculture potential and fertility of soil in Najafgarh area. J Indian Water Resour Soc 32(3-4)

38. Malik VK, Singh RK, Singh SK (2010) Impact of urbanization on ground water of Gurgaon District, Haryana, India. Int J Rural Dev Manag Stud 5(1):45-57

39. Manta DS, Angelone M, Bellanca A, Neri R, Sprovieri M (2002) Heavy metals in urban soils: a case study from the city of Palermo (Sicily), Italy. Sci Total Environ 300(1):229-243

40. McLennan SM (2001) Relationships between the trace element composition of sedimentary rocks and upper continental crust. Geochem Geophys Geosyst 2(4)

41. Muller $G$ (1969) Index of geoaccumulation in sediments of the Rhine River. Geo J 2:108-118

42. Narain V (2009) Gone land, gone water: crossing fluid boundraries in periurban Gurgaon and Faridabad, India. Environ Urb 21(2):501-512. https://doi.org/10.1177/0956247809339660

43. Nelson EJ, Booth DB (2002) Sediment sources in an urbanizing, mixed land-use watershed. J Hydrol 264(1-4):51-68

44. Nriagu JO, Pacyna JM (1988) Quantitative assessment of worldwide contamination of air, water and soils by trace metals. Nature 333(6169):134-139

45. Odewande AA, Abimbola AF (2008) Contamination indices and heavy metal concentrations in urban soil of Ibadan metropolis, southwestern Nigeria. Environ Geochem Health 30(3):243-254

46. Ogundele DT, Adio AA, Oludele OE (2015) Heavy metal concentrations in plants and soil along heavy traffic roads in North Central Nigeria. J Environ Anal Toxicol 5(334):2161-0525

47. Parth V, Murthy NN, Saxena PR (2011) Assessment of heavy metal contamination in soil around hazardous waste disposal sites in Hyderabad city (India): natural and anthropogenic implications. J Environ Res Manag 2(2):027-034

48. Patra S, Sahoo S, Mishra P, Mahapatra SC (2018) Impacts of urbanization on land use/cover changes and its probable implications on local climate and groundwater level. J Urban Manag $7(2): 70-84$

49. Plyaskina OV, Ladonin DV (2009) Heavy metal pollution of urban soils. Eurasian Soil Sci 42(7):816-823

50. Pouyat R, Groffman P, Yesilonis I, Hernandez L (2002) Soil carbon pools and fluxes in urban ecosystems. Environ Pollut 116:S107-S118

51. Pruseth KL, Yadav S, Mehta P, Pandey D, Tripathi JK (2005) Problems in microwave digestion of high-Si and high-Al rocks. Curr Sci 89:1668-1671

52. Ratha DS, Sahu BK (1993) Source and distribution of metals in urban soil of Bombay, India, using multivariate statistical techniques. Environ Geol 22(3):276-285

53. Sadhu K, Adhikari K, Gangopadhyay A (2012) Assessment of heavy metal contamination of soils in and around open cast mines of Raniganj area, India. Int J Environ Eng Res 1(2):77-85

54. Santisteban Jl, Mediavilla R, Lopez-Pamo E et al (2004) Loss on ignition: a qualitative or quantitative method for organic matter and carbonate mineral content in sediments? J Paleolimnol 32(3):287-299

55. Shafer MM, Toner BM, Overdier JT, Schauer JJ, Fakra SC, Hu S, Herner JD, Ayala A (2011) Chemical speciation of vanadium in particulate matter emitted from diesel vehicles and urban atmospheric aerosols. Environ Sci Techn 46(1):189-195

56. Sun C, Zhang J, Ma Q, Chen Y (2015) Human health and ecological risk assessment of 16 polycyclic aromatic hydrocarbons in drinking source water from a large mixed-use reservoir. Int J Environ Res public health 12(11):13956-13969
57. Thornton I (1991) Metal contamination of soils in urban areas. In: Bullock P, Gregory PJ (eds) Soils in the urban environment. Blackwell, Oxford, pp 47-75

58. Toleti BVMR, Chowdhary BS, Kumar KM, Saroha GP, Yadav M, Singh A, Sharma MP, Pandey AC, Singh PK (2000). Integrated groundwater resource mapping in Gurgaon district, India using RS and GIS techniques. In: Proceedings of the 21st Asian Conference on Remote Sensing, Taipei, Taiwan, pp 4-8

59. Tomlinson DL, Wilson JG, Harris CR, Jeffrey DW (1980) Problems in the assessment of heavy-metal levels in estuaries and the formation of a pollution index. Helgol Meeresunters 33(1):566-575

60. Tripathi JK, Rajamani V (1999) Geochemistry of the loessic sediments on Delhi ridge, eastern Thar Desert, Rajasthan: implications for exogenic processes. Chem Geol 155(3):265-278

61. Tripathi A, Misra DR (2012) A study of physico-chemical properties and heavy metals in contaminated soils of municipal waste dumpsites at Allahabad, India. Int J Environ Sci 2(4):2024

62. Ugochukwu UC, Onuorah AL, Okwu-Delunzu VU, Odinkonigbo UL, Onuora OH (2019) Ecological and human health exposure risks to heavy metals in Oji River sediments: effect of abattoir and power station. SN Appl Sci 1(5):452

63. USDOE (2011) The risk assessment information system (RAIS). US Department of Energy's Oak Ridge Operations Office (ORO), Argonne, IL

64. USEPA (1997) Exposure factors handbook. EPA/600/P-95/002Fa. Office of Research and Development, Washington, DC, USA

65. USEPA (2001) Risk assessment guidance for superfund: volume III-part a, process for conducting probabilistic risk assessment, 20460. EPA540-R-02-002. Office of Emergency and Remedial Response, Washington, DC, USA

66. USEPA (2011) Regional Screening Level table (RSL). Regional Screening Levels of Chemical Contaminants at Superfund Sites

67. USEPA (1989) Risk assessment guidance for superfund: interim final, vol 1. Office of Emergency and Remedial Response, US Environmental Protection Agency

68. Vodyanitskii YN (2015) Organic matter of urban soils: a review. Euras Soil Sci 48(8):802-811

69. Watson TL (1912) Vanadium and chromium in rutile and the possible effect of vanadium on color. J Wash Acad Sci 2(18):431-434

70. WHO (1996) Permissible limits of heavy metals in soil and plants. World Health Organization, Geneva

71. Wilcke W, Müller S, Kanchanakool N, Zech W (1998) Urban soil contamination in Bangkok: heavy metal and aluminium partitioning in topsoils. Geoderma 86(3):211-228

72. Wolińska A, Banach A, Szafranek-Nakonieczna A, Stępniewska Z, Błaszczyk M (2018) Easily degradable carbon-an indicator of microbial hotspots and soil degradation. Int Agrophys 32:123-131

73. Wong CS, Li X, Thornton I (2006) Urban environmental geochemistry of trace metals. Environ Pollut 142(1):1-16

74. Yang Z, Lu W, Long Y, Bao X, Yang Q (2011) Assessment of heavy metals contamination in urban topsoil from Changchun City, China. J Geochem Explor 108(1):27-38

75. Yu S, Zhu YG, Li XD (2012) Trace metal contamination in urban soils of China. Sci Total Environ 421:17-30

76. Zhao K, Fu W, Qiu Q, Ye Z, Li Y, Tunney H et al (2019) Spatial patterns of potentially hazardous metals in paddy soils in a typical electrical waste dismantling area and their pollution characteristics. Geoderma 337:453-462

Publisher's Note Springer Nature remains neutral with regard to jurisdictional claims in published maps and institutional affiliations. 